\title{
Archeological Testing of 41B0185 A Possible Civil War Era Military Camp, West Columbia, Brazoria County, Texas
}

Diane C. Dismukes

Follow this and additional works at: https://scholarworks.sfasu.edu/ita

Part of the American Material Culture Commons, Archaeological Anthropology Commons, Environmental Studies Commons, Other American Studies Commons, Other Arts and Humanities Commons, Other History of Art, Architecture, and Archaeology Commons, and the United States History Commons

Tell us how this article helped you.

This Article is brought to you for free and open access by the Center for Regional Heritage Research at SFA ScholarWorks. It has been accepted for inclusion in Index of Texas Archaeology: Open Access Gray Literature from the Lone Star State by an authorized editor of SFA ScholarWorks. For more information, please contact cdsscholarworks@sfasu.edu. 


\section{Archeological Testing of 41B0185 A Possible Civil War Era Military Camp, West Columbia, Brazoria County, Texas}

\section{Licensing Statement}

This is a work produced for the Texas Department of Transportation (TxDOT) by the report producer. TxDOT and the report producer jointly own all rights, title, and interest in and to all intellectual property developed under TXDOT's contract with the report producer. The report may be cited and brief passages from this publication may be reproduced without permission provided that credit is given to both TXDOT and the report producer. Permission to reprint an entire chapter, section, figures or tables must be obtained in advance from either the Supervisor of the Archeological Studies Branch, Environmental Affairs Division, Texas Department of Transportation, 125 East 11th Street, Austin, Texas, 78701 or from the report producer. 


\section{TEXAS DEPARTMENT OF TRANSPORTATION ENVIRONMENTAL AFFAIRS DIVISION}

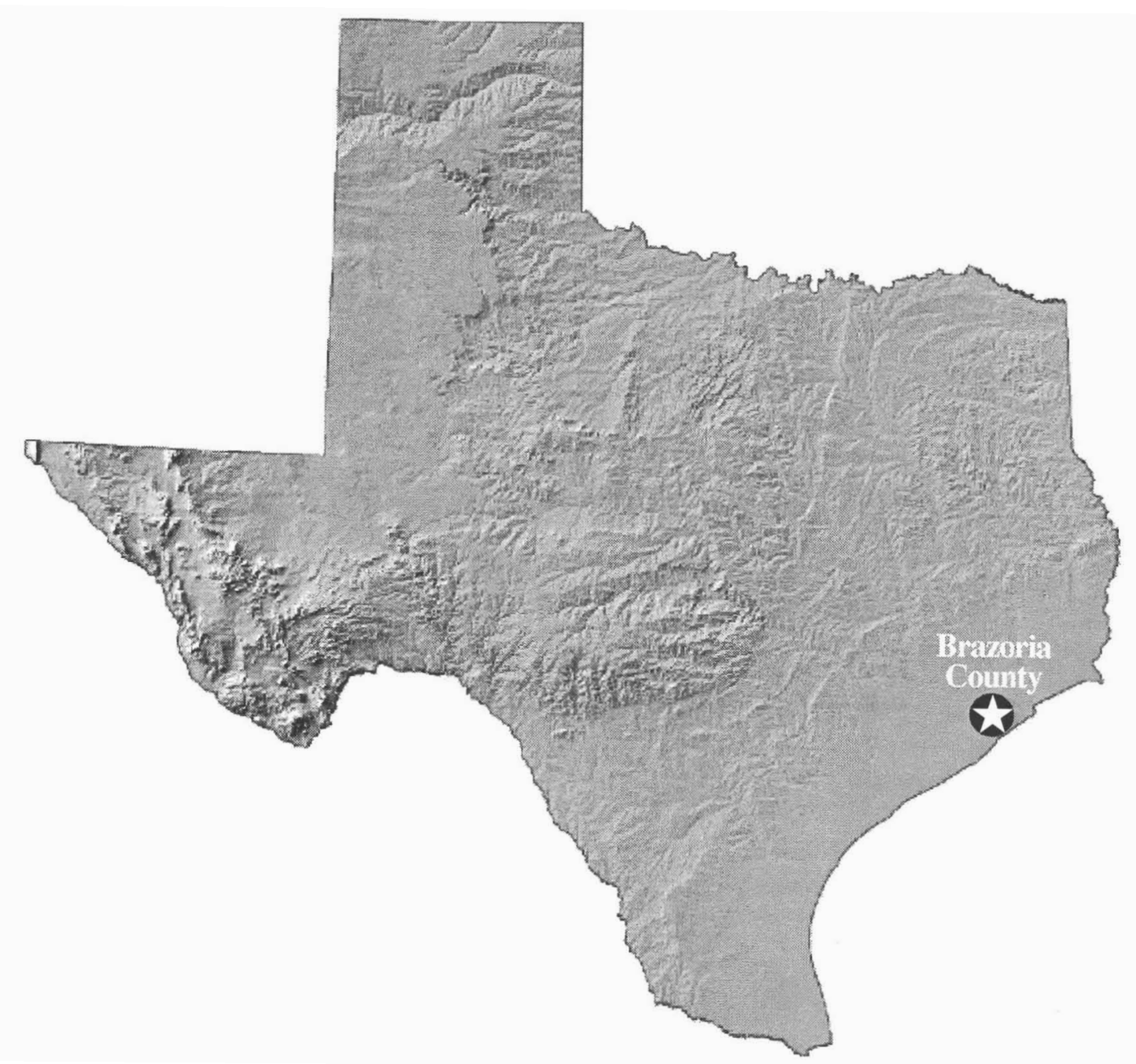

ARCHEOLOGICAL TESTING OF 41B0 185 - A POSSIBLE CIVIL WAR ERA MILITARY CAMP, WEST COLUMBIA, BRAZORIA COUNTY, TEXAS

\section{by Diane C. Dismukes TXDOT:}

ENVIRONMENTAL AFFAIRS DIVISION GULTURAL RESOURCES LIBRARY 


\section{ARCHEOLOGICAL TESTING OF $41 \mathrm{BO} 185$ A POSSIBLE CIVIL WAR ERA MILITARY CAMP, WEST COLUMBIA, BRAZORIA COUNTY,TEXAS}

Occasional Papers of the Archeological Studies Program

Volume 2, No. 2

by Diane C. Dismukes

Texas Department of Transportation

Environmental Affairs Division

Archeological Studies Program

Austin, Texas 


\title{
ARCHEOLOGICAL TESTING OF 41B 0185 A POSSIBLE CIVIL WAR ERA MILITARY CAMP, WEST COLUMBIA, BRAZORIA COUNTY, TEXAS
}

\author{
Occasional Papers of the Archeological Studies Program \\ Volume 2, No. 2
}

Copyright 2003 by the Texas Department of Transportation (TxDOT)

All rights reserved.

Published by the Texas Department of Transportation

September 2003 Austin, Texas

on acid-free paper

For further information on this and other TxDOT archeological publications

please contact:

Texas Department of Transportation

Environmental Affairs Division

ArcheologicalStudiesProgram

Owen Lindauer, Ph.D., Supervisorof

Archeological Studies Program

Archeological Studies Program

A. McGraw, Series Editor

Production of this report was directed by

Timothy Meade 


\section{MANAGEMENT SUMMARY}

In November and December 1999, staff from the TxDOTArcheological Studies Program conducted archeological investigations on a portion of site 41BO185, a reported possibleCivil War-era military encampment, within the boundaries of a proposed widening project on SH 35 in Brazoria County. The archeological investigations consisted of a combination backhoe trenching and hand-dug test units excavated across the portion of the site within the project area to locate and identify features and artifact concentrations. The goal of the testing was to determine the integrity of the portion of the site within the Area of Potential Effect (APE) and to determine whether this portion of the site is eligible for inclusion on the National Register of Historic Places (NRHP).

The archeological investigations identified a cistern, a brick scatter that may represent the remains of a collapsed chimney, a fireplace base, post molds, and various artifacts. The features appeared to represent a structure or structures that date to about the period of the Civil War. However, they are more likely related to a domestic structure, rather than a military camp site. The most likely civil war related artifact found during the fieldwork was a fragment of a bayonet. However, no definitive archeological evidence that a Civil War camp site was at this location was found during fieldwork. It is possible that ground disturbing activity, such as sod harvesting, may have erased any trace of the site.

Based on the results of this investigation, the portion of 41B 0185 located within the project boundaries will not contribute to the potential NRHP eligibility of the site. No further archeological work is recommended for the portion of the site within the present $\mathrm{SH} 35$ project area. 


\section{TABLE OF CONTENTS}

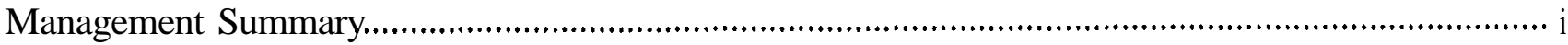

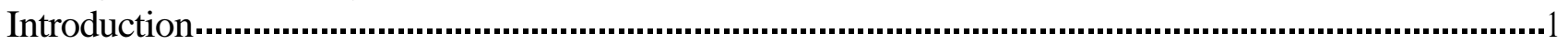

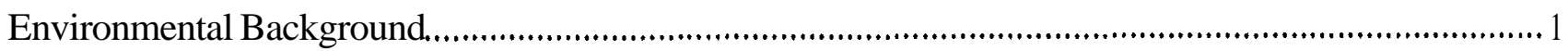

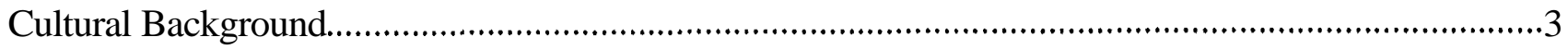

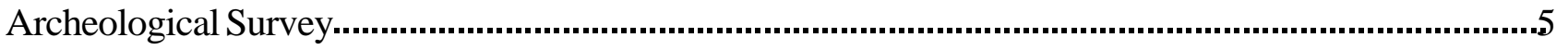

Archeological Testing..................................................................................................................

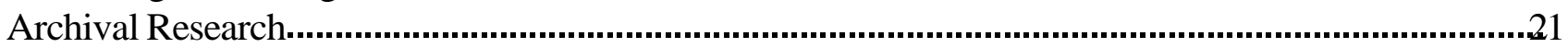

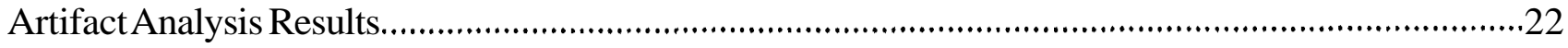





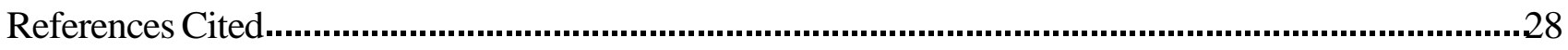

\section{LIST OF FIGURES}

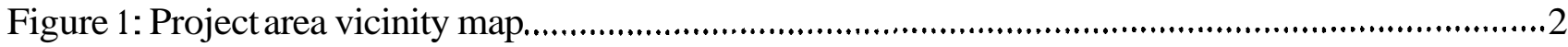

Figure 2: Map of the original land grant of Josiah H Bell....................................................................4

Figure 3: The site map from the 1994 TxDOT survey...........................................................................6

Figure 4: Brick Scatter in wooded area north of SH 35 and east of CR 438.............................................7

Figure 5: Excavated trench across the southern end of the brick scatter......................................................

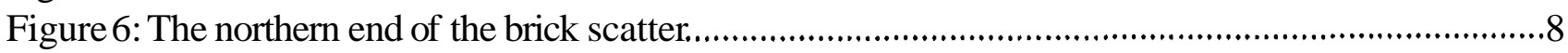

Figure 7: Brick laid in a pattern.................................................................................................

Figure 8: Site map of work performed during the testing of 4 1BO185 .................................................. 10

Figure 9: Site map of trenched area................................................................................................... 11

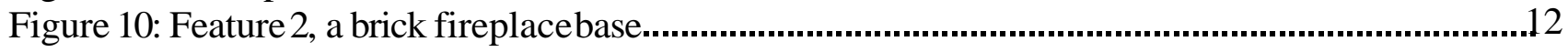

Figure 11: Remains of wooden post \#1....................................................................................... 13

Figure 12: An example of post and beam construction w/brick chimneys....................................................13

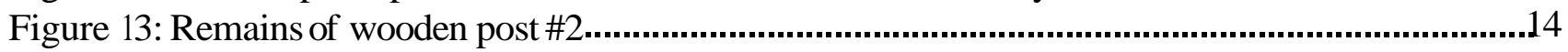

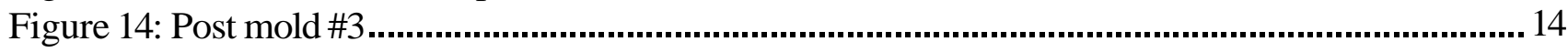

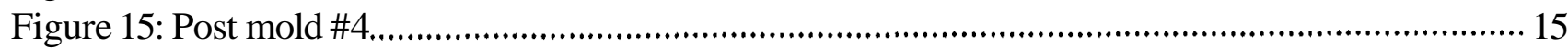

Figure 16: Feature 3. a brick walled cistern...................................................................................... 15

Figure 17: Feature 4. a burn pit with cast iron stove parts on the surface....................................................16

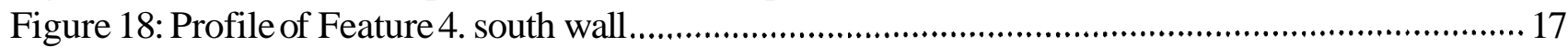

Figure 19: Feature 5, a second brick fireplace base...............................................................................17

Figure 20: Aerial photograph of project area.................................................................................17

Figure 21: Ceramic fragments from the artifactscatter west of Feature 2................................................22

Figure 22: Yellowware rim sherd from the artifact scatter west of Feature2

Figure 23: A white milk glass disk recovered from Feature 4.............................................................26

\section{LIST OF TABLES}

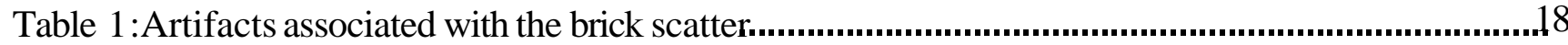

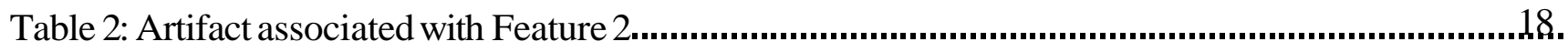

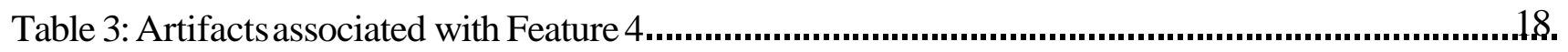

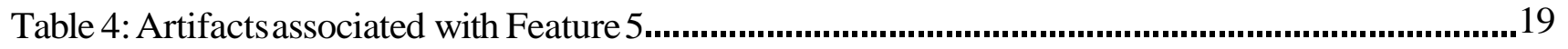

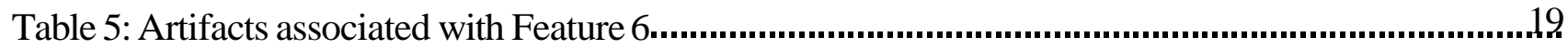

Table 6: Artifactsassociated with the scraped areas West of Feature 2...................................................20 


\section{INTRODUCTION}

Improvements to State Highway 35 (SH 35) were authorized as a Demonstration Project by the Intermodal Surface Transportation Efficiency Act of 1991 and the project is included in the 1993 Transition Project Development Plan. In 1994 an Environmental Assessment was begun of proposed improvements between FM 2540 in the town of Van Vleck and State Highway 288 in Angleton, Brazoria County, Texas. As part of the Environmental Assessment an archeological survey was performed between June 7 and August 19 of that year. During the course of the survey, historic debris, bricks and reports of the presence of a cistern resulted in the recording of site $41 \mathrm{~B} 0185$.

A report of the archeological investigations along SH 35 was submitted to the Texas Historical Commission Department of A ntiquities Protection with the recommendation that 41 B 0185 required testing for a National Resister of Historic Places (NRHP) determination of eligibility. Concurrence with that recommendation was received September 15, 1994. Local informants reported that the location was the site of a Civil War campground, and their reports of military type artifacts previously collected from the area supported that identification. The site's location remained in private ownership while TxDOT finalized the design of SH 35.

In November, 1999 the Archeological Studies Program was notified by the Houston District office that access to the property had been approved. Between November 15 and December 1 of 1999 subsurface testing was performed in the area to determine the site's integrity and significance. A metal detector was employed within the proposed right of way to locate concentrations of metal artifacts. Although a combination of backhoe trenches and hand-dug test units were excavated at intervals across the entire field in an attempt to locate and identify features and artifact concentrations, no clear evidence of the Civil War campagn was found. The following report contains the results of those explorations, and the recommendations for future work at 41B0185.

\section{ENVIRONMENTAL BACKGROUND}

Brazoria County is located within the coastal prairie along the Gulf of Mexico in the southeastem portion of Texas (Figure 1). The county is 1,407 square miles in size, with sixty feet being it's highest point above sea level. The annual rainfall is fifty-two inches and the mean annual temperature is 69 F. Hurricanes and tropical depressions that often result in extensive flooding are common in the area. During particularly large floods it has been said that the entire county, with the exception of Damon Mound, has been underwater. As a result of it's proximity to the Gulf Coast and recurrent flooding episodes, the soils are chiefly alluvial loams and silty clays that are highly productive for agricultural purposes. The growing season averages 309 days a year and this long growing season, in conjunction with the rich alluvial soil, influenced the early historic period settlement patterns and land use of the area.

The Brazos River divides the county with the one-third west of the river covered by hardwoods and the eastern portion being mainly prairie. When Anglo settlers arrived early in the 19th century, they found abundant wildlife such as deer, bear, turkey and fish. Also abundant, particularly on the grasslands, were large herds of feral cattle, resulting from the earlier importation of cattle into the area to the west and south by the Spanish.

The soils in the project area are Asa silt loam and Asa silty clay loam (Crenwelge 198 1). These soils are identified as nearly level. Undisturbed Asa soils have a surface layer of neutral, very dark grayish brown silt loam 12 to 14 inches thick. This is underlain by a moderately alkaline calcareous, light brown loam below which is firm calcareous reddish yellow silty clay loam. The Asa soil complexes are rarely flooded and this type of land is used mostly for pasture and crop production. This soil type indicates an area that would have been in dense hardwoods at the time of colonization. 
This Page Redacted Per THC Policy 


\section{CULTURAL BACKGROUND}

The earliest recorded residents of what is now Brazoria County consisted of small bands of Karankawa Indians. They were foragers and moved frequently to exploit the natural game, flora and coastal resources on a seasonal basis. A few of these Native Americans remained in the area until 1824 when the battle of Jones Creek resulted in their expulsion by the Anglo settlers of Austin's colony.

Brazoria County was not settled by the Spanish and there was no European settlement in the area until the early 1820 's. However, some early activity in the area included excursions by A IvarNunez Cabeza de Vaca, after a shipwreck; Alonso De Leon, searching for La Salle; Joaquin de Orobio y Basterra, searching for French intruders; Spanish settlers, trading with the Indians; and possibly the pirate Jean Laffite, to rendezvous and bury treasure at the mouth of the Brazos River.

The area was selected for settlement by Stephen F. Austin in 1824 and 89 of Austin's "Old Three Hundred" received grants in what is now Brazoria County. The earliest communities were Velasco, East Columbia (Bells' Landing or Marion), Columbia (now West Columbia), and Brazoria.

Josiah Hughes Bell was the founder of both East and West Columbia. He had been born in South Carolina in 1791. Bell apprenticed with his uncles in the hat business in Tennessee and then moved to Missouri Territory where he became a justice of the peace and served in the Indian wars after the war of 1812 . He went back to manufacturing hats and dealt in pelts for a while but in 1818 he sold his farm in Missouri, married Mary Eveline McKenzie and, after a short time in Natchitoches, Louisiana, moved to Texas with Austin in 1821. Josiah and Mary Eveline's son, Thaddeus C. Bell, was the second white child born in Austin's colony.

Bell was an important figure in the colony, and took charge of business affairs while Austin was in Mexico. On February 10, 1823, Bell's land grants were located, by surveyor Horatio Chriesman, on the west side of the lower Brazos River and in January of 1824 he moved to Bell's
Creek (now Varner Creek) (Figure 2). By 1829 a community had grown up around Bell's Landing, which became known as Marion and was an important inland port. Bell raised sugar cane along the creek's banks and subsequently in 1826 laid out the town of Columbia two miles west of Marion which then became known as East Columbia. In 1837, after Texas won it's independence from Mexico, Josiah Bell sold his holdings in M arion/East Columbia and moved to West Columbia, where he died on May 17, 1838.

Columbia was the capital of the Republic of Texas from September to December 1836, and it was there that the First Congress of the Republic of Texas convened and Sam Houston was inaugurated as president. In November of that year the capital was moved to the new city of Houston on Buffalo Bayou. A month later on December 27, 1836, Stephen F. Austin, Secretary of State, died in Columbia at the home of George B. McKinstry.

During the civil war there were at least 26 military Camps located in Brazoria County (Winsor 1978) which was in the Third Military District and later in the Central Military SubDistrict of Texas. In 1863, Texas was divided into three sub-districts; an Eastern Sub-District, a Northern Sub-District; and a Western SubDistrict. The Western Sub-District was commanded successively by Brigadier Generals Hamilton P. Bee and James E. Slaughter (Beers 1968)

A number of civil war era camps were established along the Brazos River as a main line of resistance between Matagorda Bay and Houston. The structures at these camps were described as being little pens, thatched with Spanish moss, but warm and large enough to accommodate two soldiers (Winsor 1978). There were also more permanent installations with more durable architecture. According to Winsor (1978) the outskirts of East Columbia was the site of a small shop in which George and William Dance produced the handsome "Dance Pistol." In 1863 the brothers formed a partnership with a Mr. Parks and operated a business there until 1864, when Federal troop movements along Caney Creek increased. At that time their machinery and equipment were moved to Anderson. 


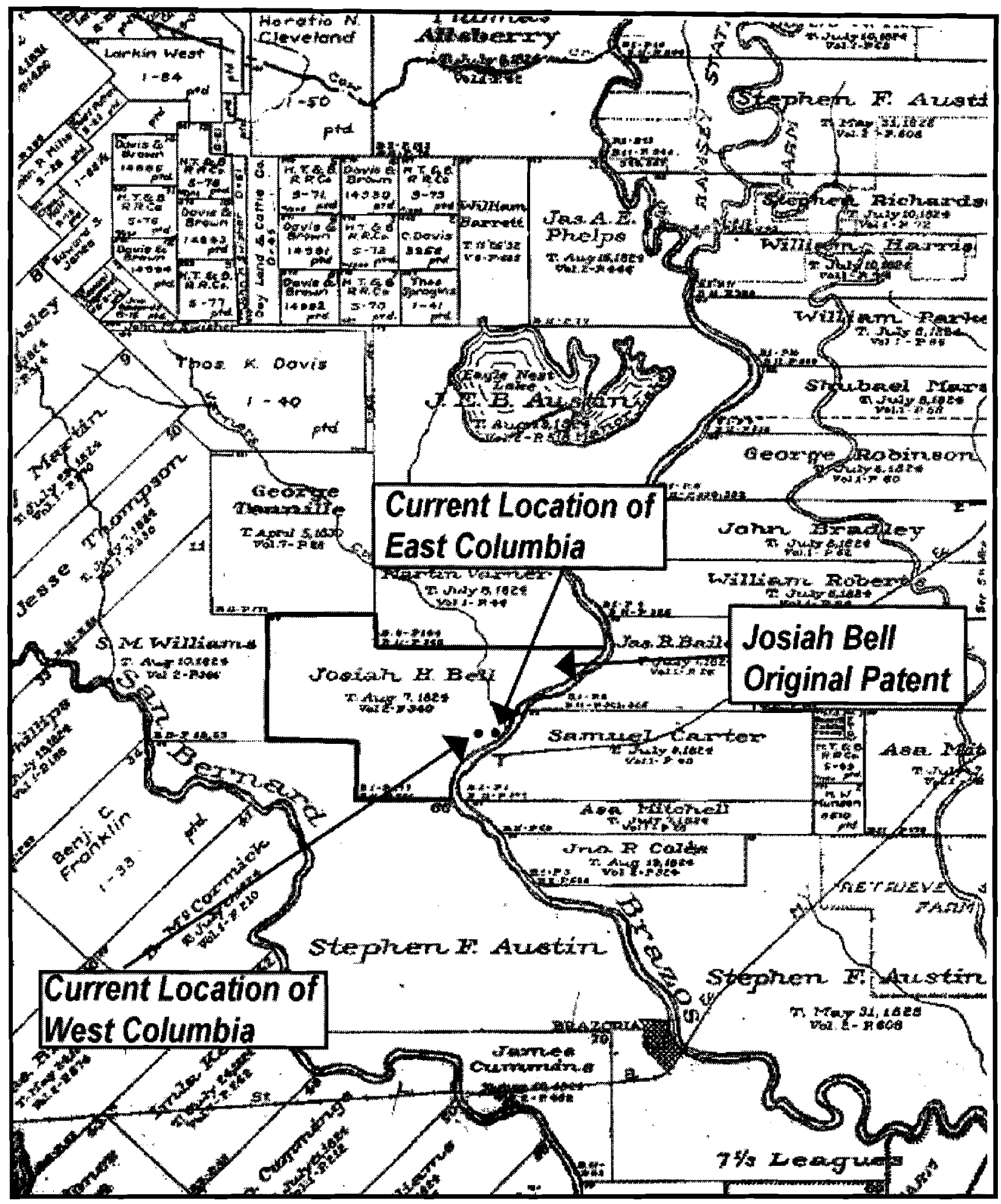

Figure 2: The Original Land Grant of Josiah H. Bell. Bell established both East and West Columbia. East Columbia was first named Marion. West Columbia was originally named Columbia (Map on file at TxDOT). 
One of the two permanent encampments recorded by Winsor (1978) may have been located on what is now the project area. Camp Bernard Bee was described by him as being located near Columbia on the Brazos River. Major H. Wilke was the commander of the garrison in 1864. The 13thTexas Volunteer Infantry was stationed there in May of 1865 . The post became the headquarters for the Central Sub-district of Texas on April 30, 1865, at which time Colonel Joseph Bates replaced Major Wilke as commanding officer.

The other permanent encampment, Camp Slaughter, was located on the Brazos River near Columbia on property owned by Mr. Brown. The encampment named for Brigadier General J.E. Slaughter, was established by members of the 4th Infantry Regiment, Texas State Troops. Camp Slaughter had a large hospital and several barracks.

The names of both of these encampments derived from the two generals that commanded the Western Sub-District of Texas. Either of these encampments could have been located in the area of the proposed SH 35 improvements.

\section{ARCHEOLOGICAL SURVEY}

Between June 7 and August 19, 1994, staff members of the Archeological Studies Program, Environmental Affairs Division, Texas Department of Transportation; conducted a pedestrian survey with shovel testing of the proposed SH 35 right of way. They spoke with a local informant who indicated that there was a Civil War period encampment just east of the city limits of West Columbia. As a result of this information, an intensive survey was conducted on two tracts of land at this location. One of the tracts contained an open field of mown grass, used for sod production. Private collectors had reportedly found a buckle, several buttons, and numerous metal artifacts including a cannonball at this location.

Seven shovel tests were excavated and some unidentifiable metal fragments and brick fragments were recovered. The land owner, Mr. Marcus Weems reported that he had knocked the top of a brick cistern in and filled it in 1946.
Shovel Test 5 (Figure 3), recovered brick fragments, glass, and metal fragments and it was concluded that these were in the location of the cistern. Mr. A.H. Weems, brother of the landowner, stated that a house was located near the cistern as recently as the turn of the century.

Two additional shovel tests were placed in the wooded area to the east of the open field because local informants had indicated that the site extended in that direction. These shovel tests located an area of brick scatter. In addition locals indicated that the site also extended across SH 35 and to the south for some unknown distance. As a result of this survey, site 41B 0185 was recorded and recommended for testing.

\section{ARCHEOLOGICAL TESTING}

The recorded site, 4 1B 0185, is located on the north side of SH 35 just outside the eastern city limits of West Columbia, Brazoria County, Texas (see Figure 1). The site was recorded in 1994 as a result of information supplied by a local informant and survey with shovel testing. It was recommended that the site should be tested in order to determine its historical significance and the THC concurred. The site was tested between November 15 and December 1, 1999. Diane Dismukes of the Archeology Studies Program of TxDOT directed the testing project. Jesus Gonzalez, Julie Lane, and Pat McLaughlin of the Environmental Affairs Division in Austin and Kurt Kamman, Environmental Coordinator with the Houston District Office, assisted with the field work.

\section{The Brick Scatter}

The brick scatter in the wooded area at the extreme eastern end of the site delineated in 1994, was relocated. At this location, TxDOT acquired 125 feet of new right of way and this distance was measured with stakes set to mark the proposed right of way. An area of approximately seven feet square was cleared of brush and soil down to the surface of the brick at the southern end of the scatter (Figure 4). The surface of the brick was between 4 to 8 inches below current ground surface. The bricks 







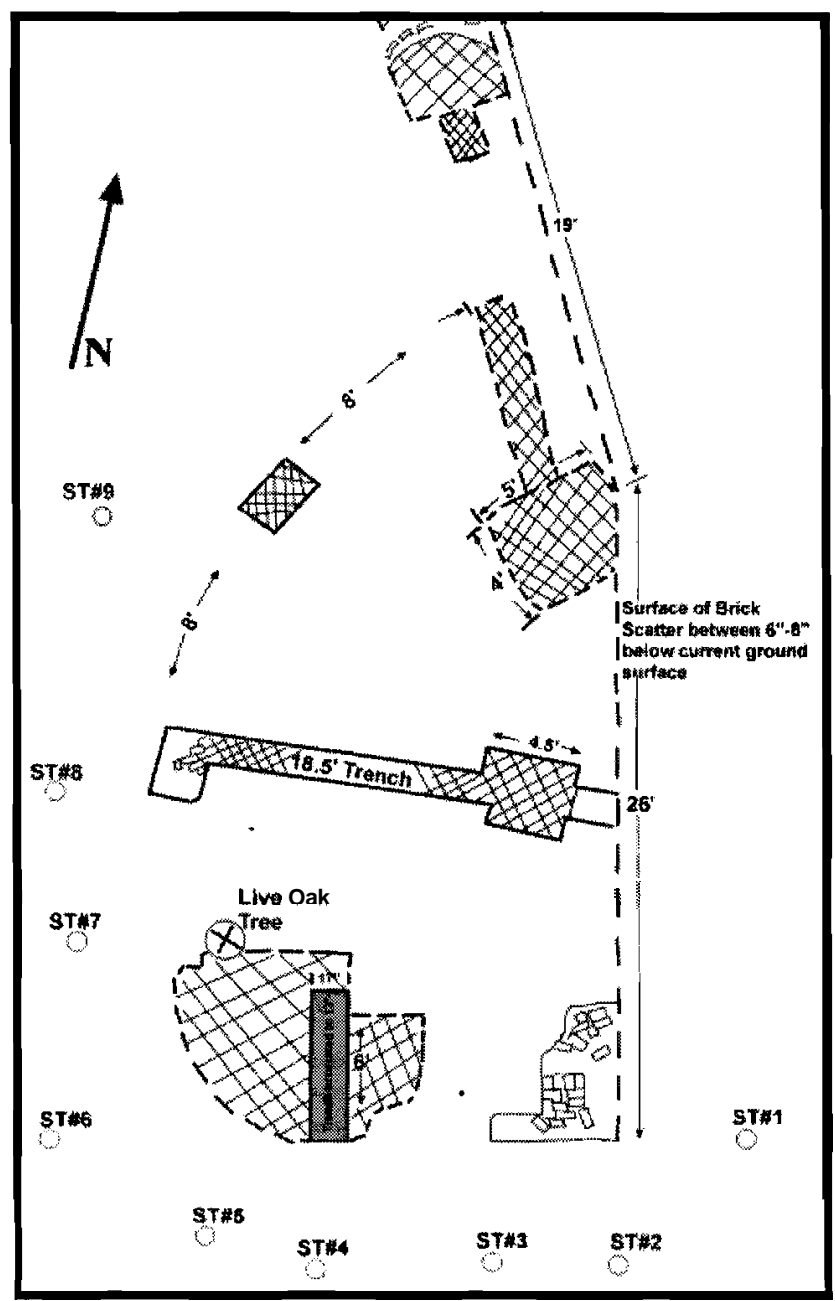

Figure 4: Brick Scatter in wooded area north of SH 35 and east of CR 438.

appeared to be laying flat on the ground, however there was no pattern to their arrangement and broken and half bricks were present. The bricks were used with many still having mortar adhering to their surfaces. The bricks are soft paste, some having portions of glaze, and may have been produced during the antebellum period. The only artifact present in the removed overburden from this area was one bone fragment. Bricks which are part of the unidentified standing walls of the sugar house and cistern at the Varner Hogg Plantation, just north of the project area, were examined and found to be similar to the bricks scattered at the edge of the TxDOT right-of-way.

In an attempt to ascertain the depth of the brick deposit and determine if it resulted from the fall of a wall, a north-south trench was hand excavated across the southern end of this area (Figure 5). A few artifacts consisting of another bone fragment, a piece of crockery, and a number of nails, bent in an L shape, were found scattered across the surface of the brick. Black wax and some window glass was also found near the base of a large oak tree growing through the brick rubble. Although there was some mixing, the bricks appear to be one layer thick across the area. The soil below the bricks was undisturbed and contained no cultural materials.

The brick scatter was explored as far north as the edge of the proposed right-of-way, it appeared some brick may extend beyond this limit (Figure 6). Much of the brick surface was cleared and the outer edges on the east, west, and south were located. Shovel tests were placed five feet from the outer edges of the brick and spaced at five-foot intervals all around the brick scatter (Figure 4). The soil from these tests was screened and found to be culturally sterile. No evidence of features was seen in any of the shovel tests. Occasionally when the soil was scraped from the surface, the brick appeared to have a pattern as if it had been intentially placed (see Figure 7). Whenever this apparent pattern was found those bricks were removed and the area beneath them examined. No evidence of intentional masonry work was discovered. It was decided that the apparent pattern was a result of the dumping of mortared bricks. The mortar has since dissolved from between them. This area of brick scatter was mapped and photographed (see Figure 5).

\section{The Grassy Field}

A metal detector was employed to survey the small open area just north of SH 35 east of County Road 468 near the wooded area. A buried cable was detected in this area as well as the remnants of a barbed wire fence. The area was at the time of fieldwork the location of a fireworks stand, and there was much modem trash and debris scattered about. The metal detector was then used in the large grassy field north of SH 35 and west of CR 468. A few soundings were marked along the edge of the highway, particularly in the area of some large billboards 


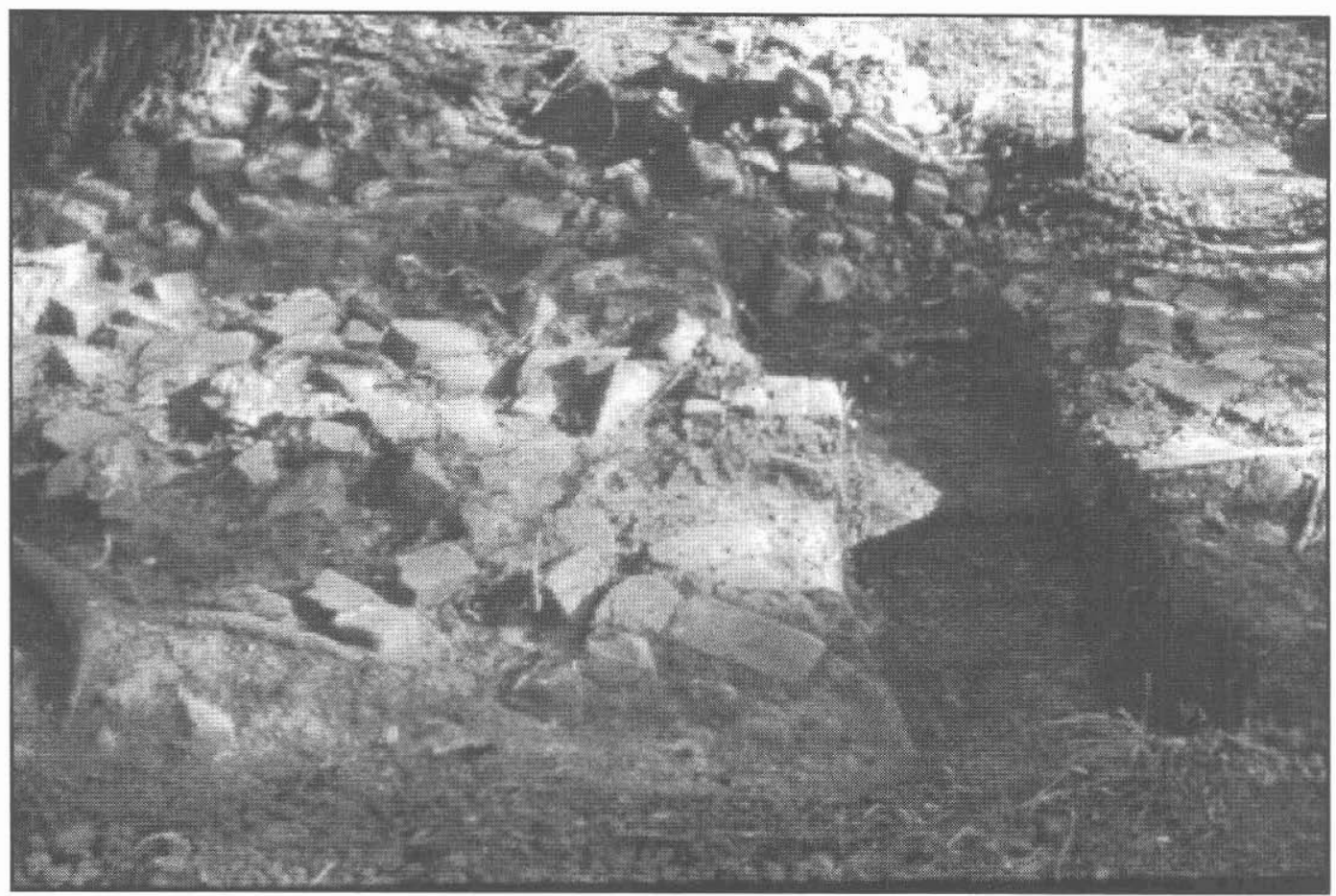

Figure 5: A trench was excavated across the southern end of the brick scatter to expose subsurface disturbance, or foundation trenches.



Figure6: The northern end of the brick scatter appears to extend beyond the northern TXD OT right of way limit which is in the upper left portion of this photo. 


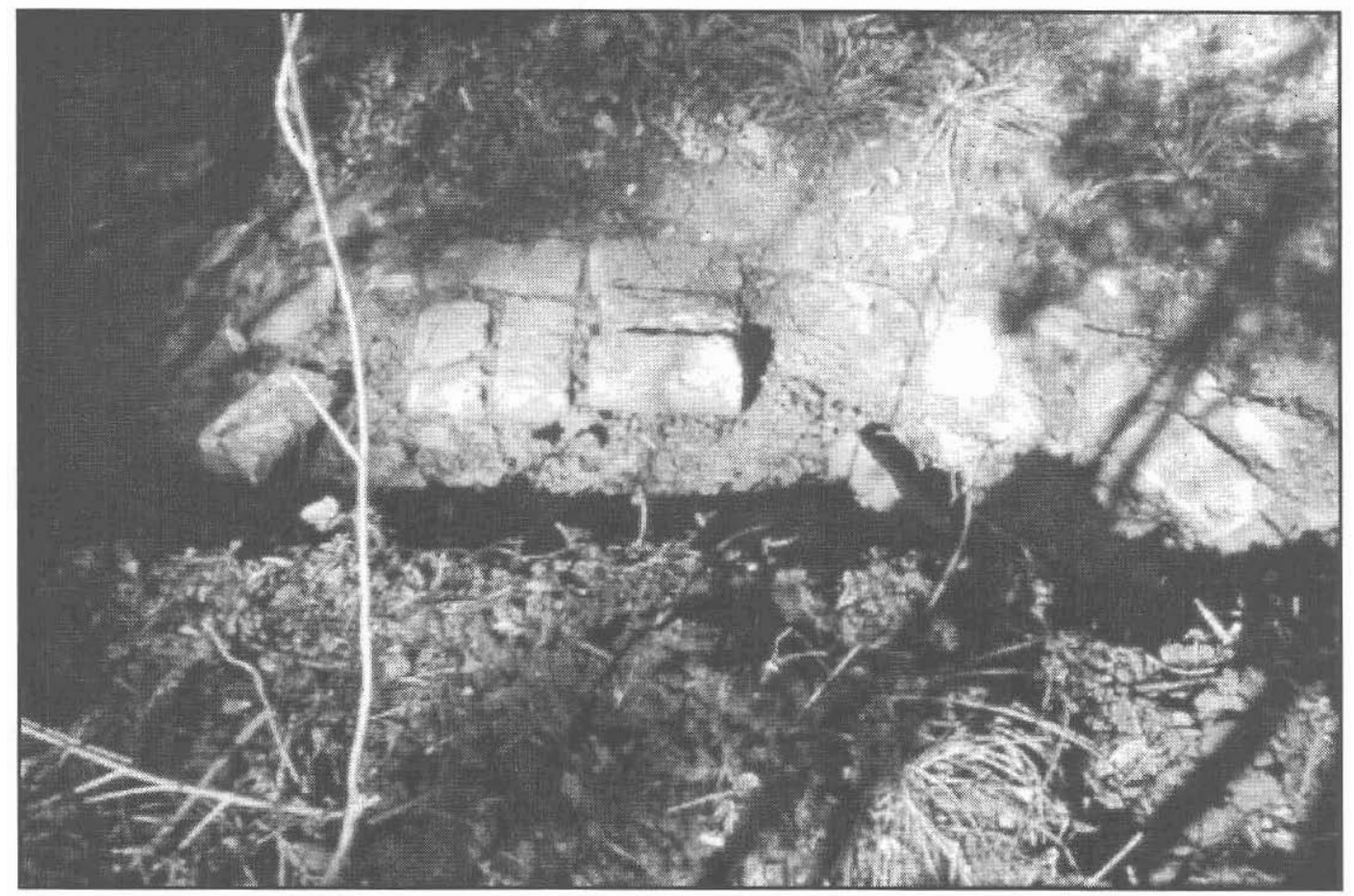

Figure 7: Some of the brick was laid in a pattern. This brick was removed but there was no evidencese of artifacts, disturbed soil, or foundation below it:

that were located there. The area identified as the location of the cistern by the survey crew was examined, and the number of buried metal objects increased dramatically. All of the objects identified with the metal detector were marked with pin flags and resulted in a fairly dense pattern. Subsurface exploration with shovel tests resulted in the location of some brick. This area was further examined by mechanical trenching by a backhoe.

On November 17, 1999, backhoe trenching was conducted in the area reported to be the location of the cistern (Figures 8 and 9). Scrape \#I located some brick chips, ironstone, whiteware, and square nails within 6 inches of the current ground surface, just below the grass roots. At about 12 inches below current ground surface the soil became lighter in color and the silt content increased. This layer was devoid of artifacts and appeared to be undisturbed. A second scrape was begun north of the first scrape and a large number of brick fragments were found with an increase in artifact density. Screens were set up and the soil that was scraped from this area was screened through $1 / 4$ inch mesh.
An area about eight feet by twelve feet was scraped in an attempt to locate a feature or an artifact concentration that would indicate a trash pile (see Figure 9). The artifacts appeared to be a general scatter and no features were located. Artifacts which were temporally or functionally diagnostic were collected. The remainder of the artifacts were examined but not collected.

Trench \# 1 was extended east of the artifact scatter and immediately located a chimney base (Figure 10). The direction of the trenching was changed to anorth to south line and in alignment with the brick feature, eight feet south of the southeast comer of the chimney base. The remains of a post were located (Figure 11). The absence of any other indications of foundation suggested that the structure had been of post and beam construction (Figure 12). and an attempt was made to identify the structure's perimeter. Some of the posts had apparently been removed or had disintegrated over time, leaving only the faint outlines of post molds (Figures 13, 14 and 15). No artifacts were present in association with either the chimney base or the posts.

When the trench was extended to the east (see Figure 9), a cistern, Feature 3, was found at 





what would have been the northeast corner of the house structure. A backhoe was used to excavate the debris in search of historic deposits that may have been present. The cistern (Figure 16) was excavated to help define the function of the site; but it was filled with sand and modern debris.

The cistern was 10 feet in diameter and six feet 10 inches deep. It was constructed of soft paste brick and was plastered on the inside and on the base. It once had a domed brick lid, most of which was found within the cistern and was removed along with all of the modern debris. No evidence of pre-1900 cultural materials was found in the cistern. Mr. Weems reported that he had filled the cistern in 1946, however some Fiesta Ware fragments were present in the cistern with the date of October 1947 stamped on the base.

An absence of cultural materials between the artifact scatter discovered at the west end of the excavations and the fireplace base, Feature 2, posed the possibility of the presence of a portion

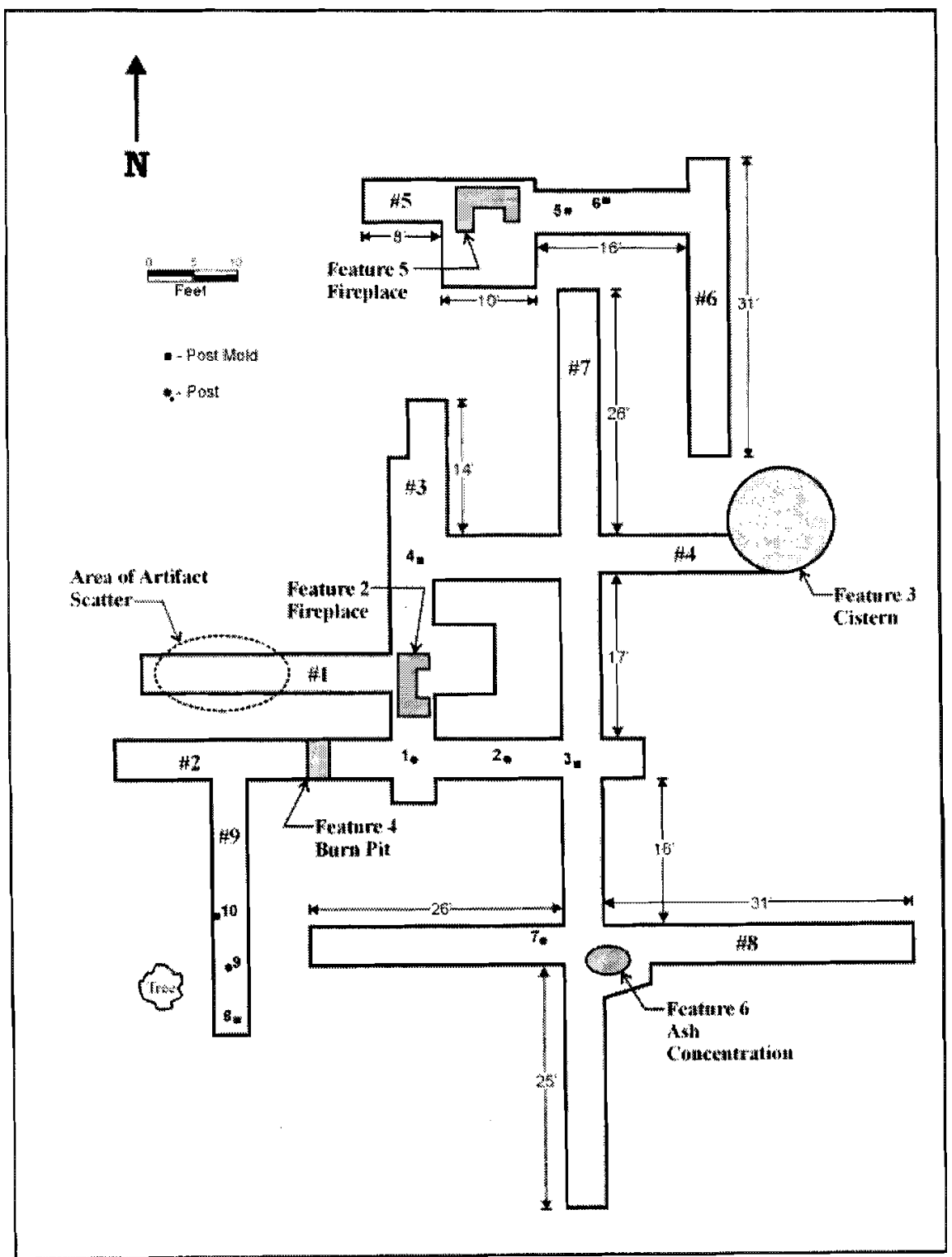

Figure 9: Site map of Trenched Area showing trenches, features, posts and post molds. and area of artifact scatter. 
of the structure in that location. The backhoe was used to excavate a trench extending west from the post located south of the fireplace (Trench \#2, see Figure 9). A bum pit (Figure 17), Feature 4, was located in this area which contained pieces of a cast iron wood stove and other assorted artifacts, including a piece of a bayonet . A profile drawing was made of this pit area which, below ground surface, was relatively free of artifacts and contained an ashy gray sandy sediment mixed with small charcoal bits (Figure 18).

The backhoe was used to: 1) excavate a trench at the west end of the project area and 2) a series of trenches across the site (see Figure 8 ). The trenches were approximately four meters in length and were placed at 20 meter intervals. The first series of trenches was placed just inside the proposed right of way at the north edge of the project area.

A second fireplace base (Feature 5) was located north of the first (Feature 2), and slightly to the east of a north south linefrom that location (Figure 19). This second fireplace is aligned 90' to the first and it was felt that either there had been a multi-room structure on the property or that there had been more than one structureat this location (see Figure 9). An attempt was made to locate posts associated with this fire place base and a disturbance was found 10 feet east of the southeast comer of the fireplace. It was so ephemeral, however that it could not be positively identified as apost mold. A second anomaly was located in this area and both were photographed and mapped. Both soil stains disappeared with the next backhoe scrape (see Figure 9).

The backhoe was used to scrape a trench across the structure location from the northern edge of the project area to the south (Trench 7, see Figure 9). Small brick chips were scattered all across the area, probably as a result of the previous disturbance. This entire trench proved to be sterile except for the previously identified post mold \#3 and a small area at the extreme southern edge 25 feet north of the current right of way limit. A small trash area containing ash, Feature 6, charcoal and a few artifacts, was located near what remained of a post, \#7. This deposit was interpreted as fire place cleanings dumped

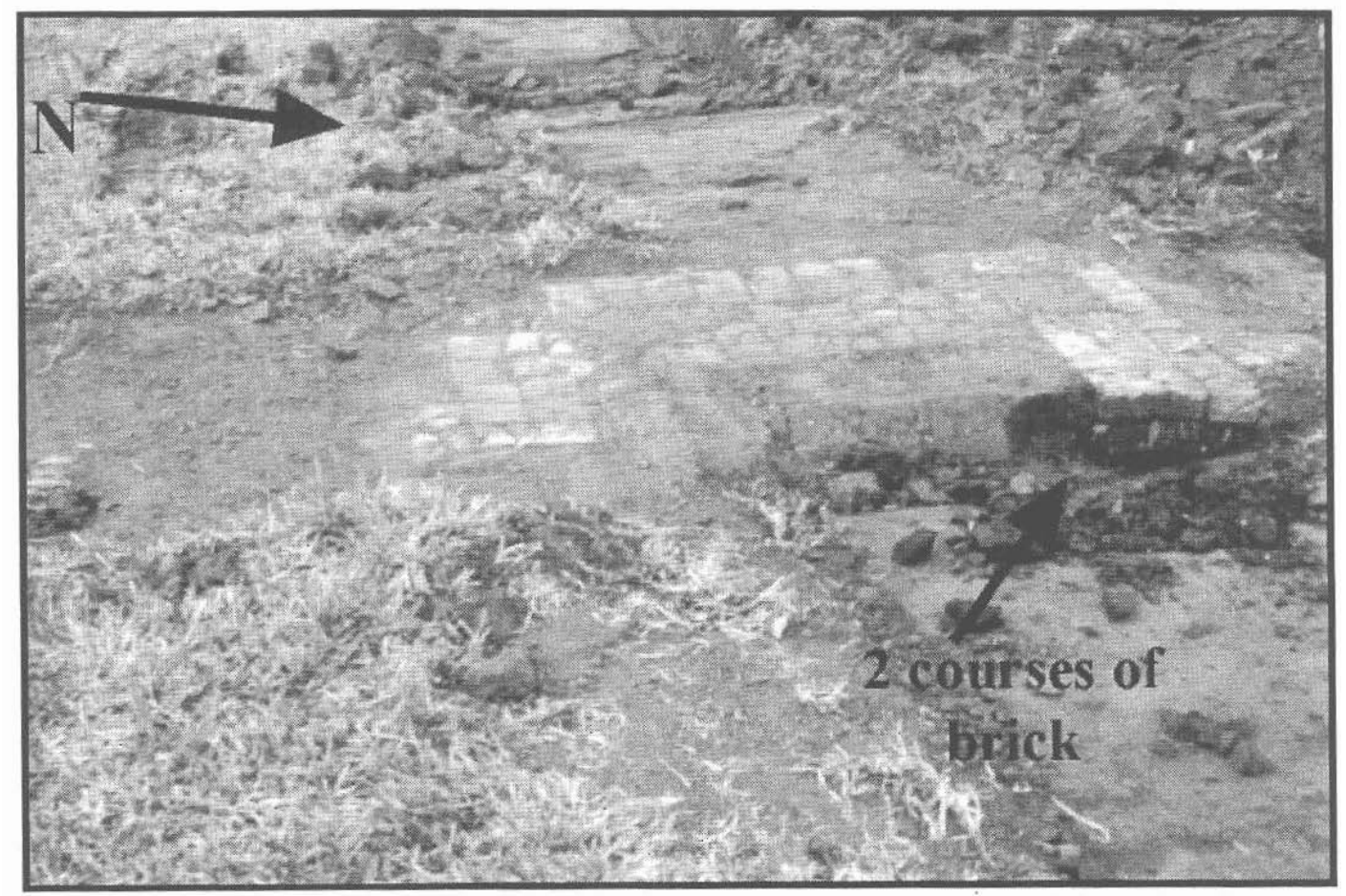

Figure 10: Feature 2, a brick fireplace base, had only two courses of brick remaining. No artifacts were found in association with this feature. 


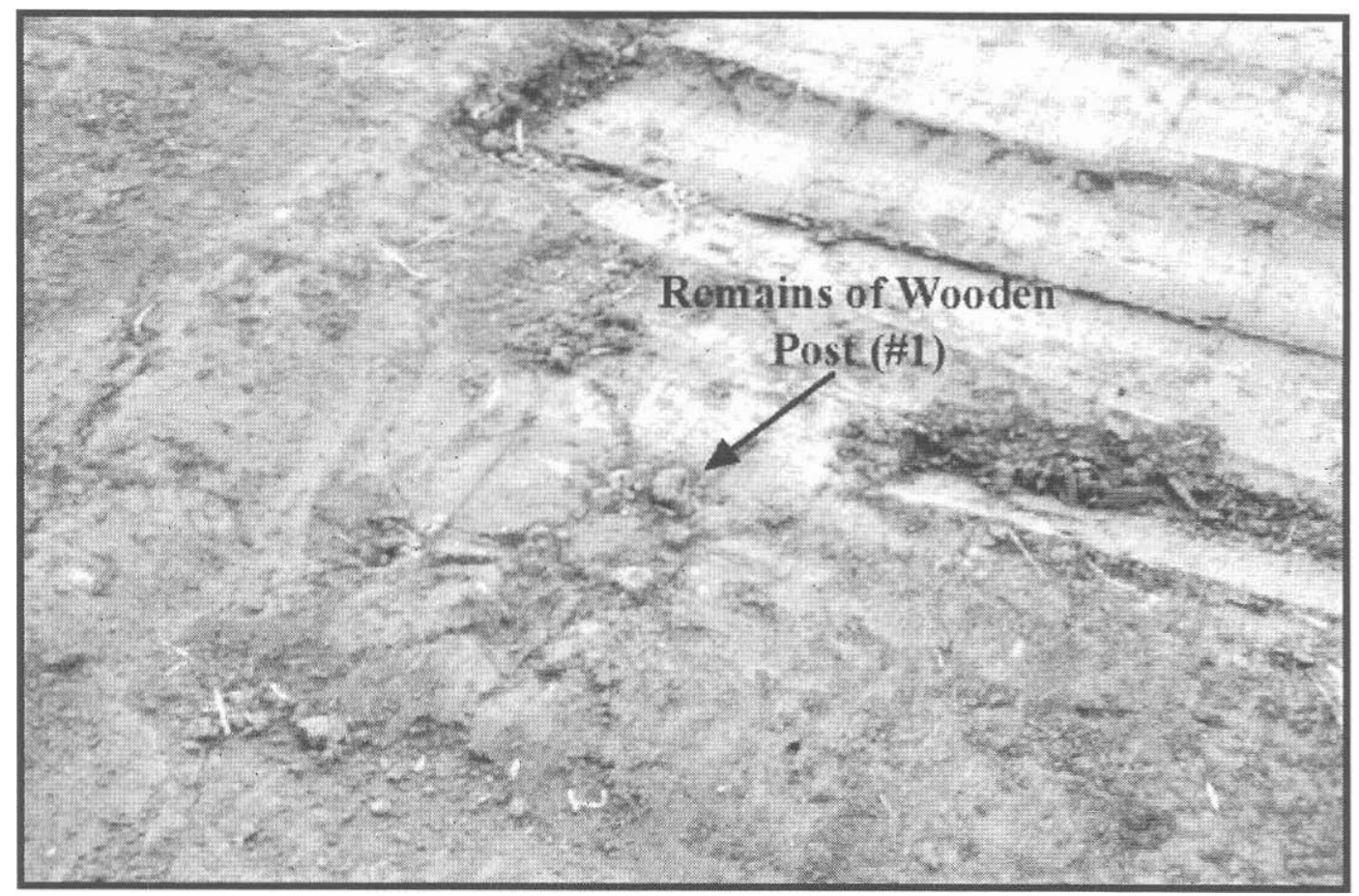

Figure 11: Post\#1 was found south of the front edge of Feature 2, the brick fireplace remains.

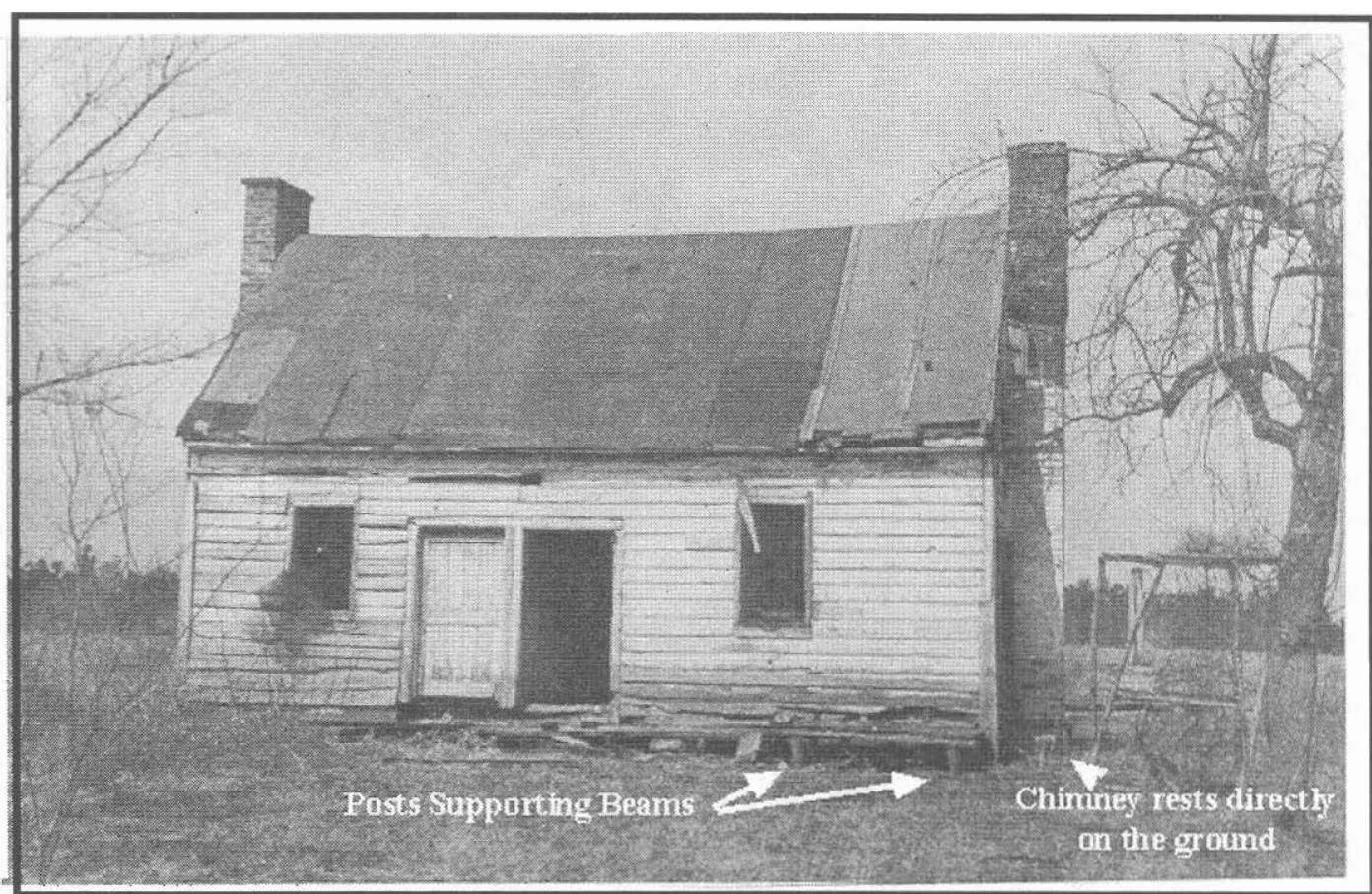

Figure 12: This is an example of post and beam construction with brick chimneys. The picture was taken by Thomas T. Waterman in 1940 and published in back of the Big House. The A rchitecture of Plantation Slavery by John Michael Vlach. This is a slavequarter from Henrico County, Virginia. 


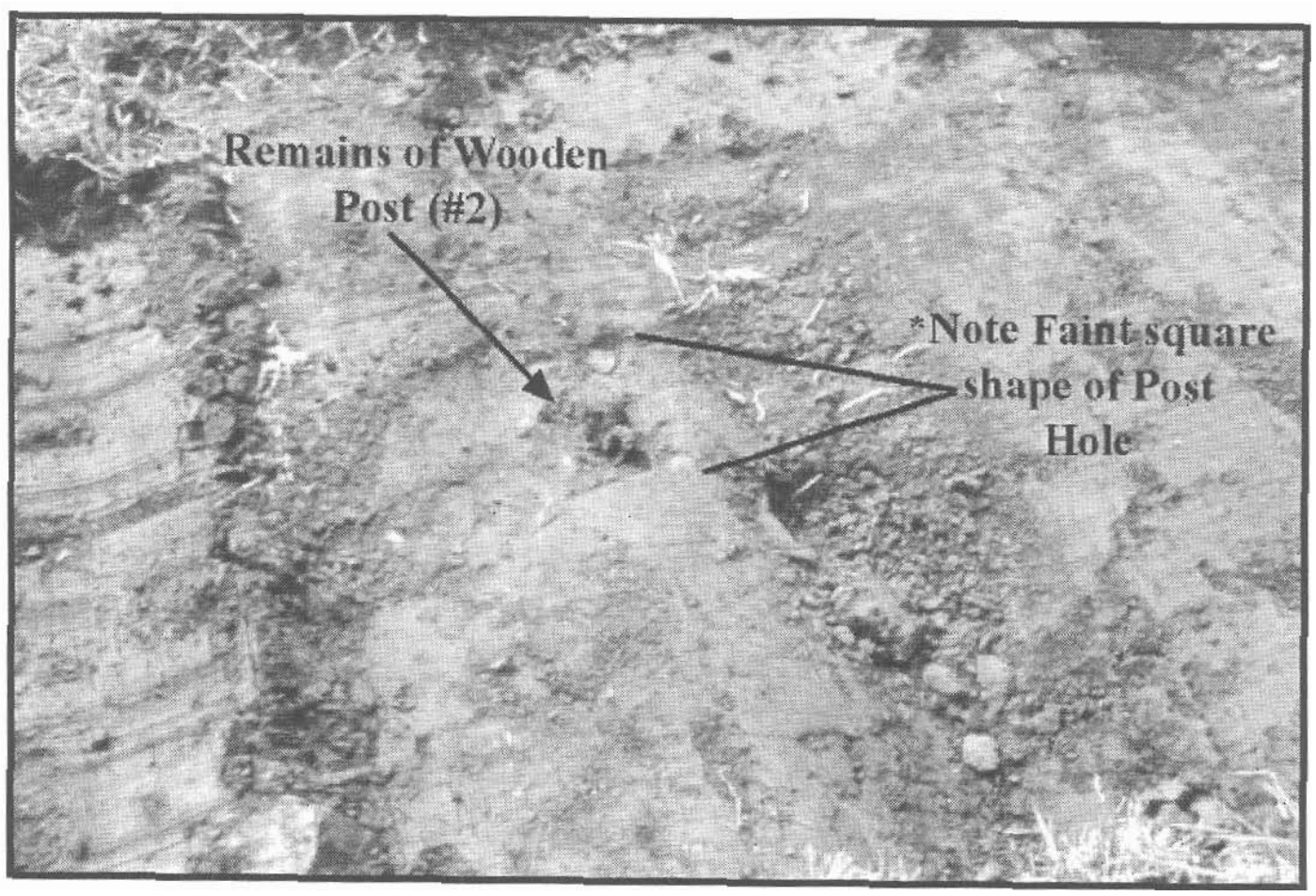

Figure 13: Post \#2 was located east of post \#1

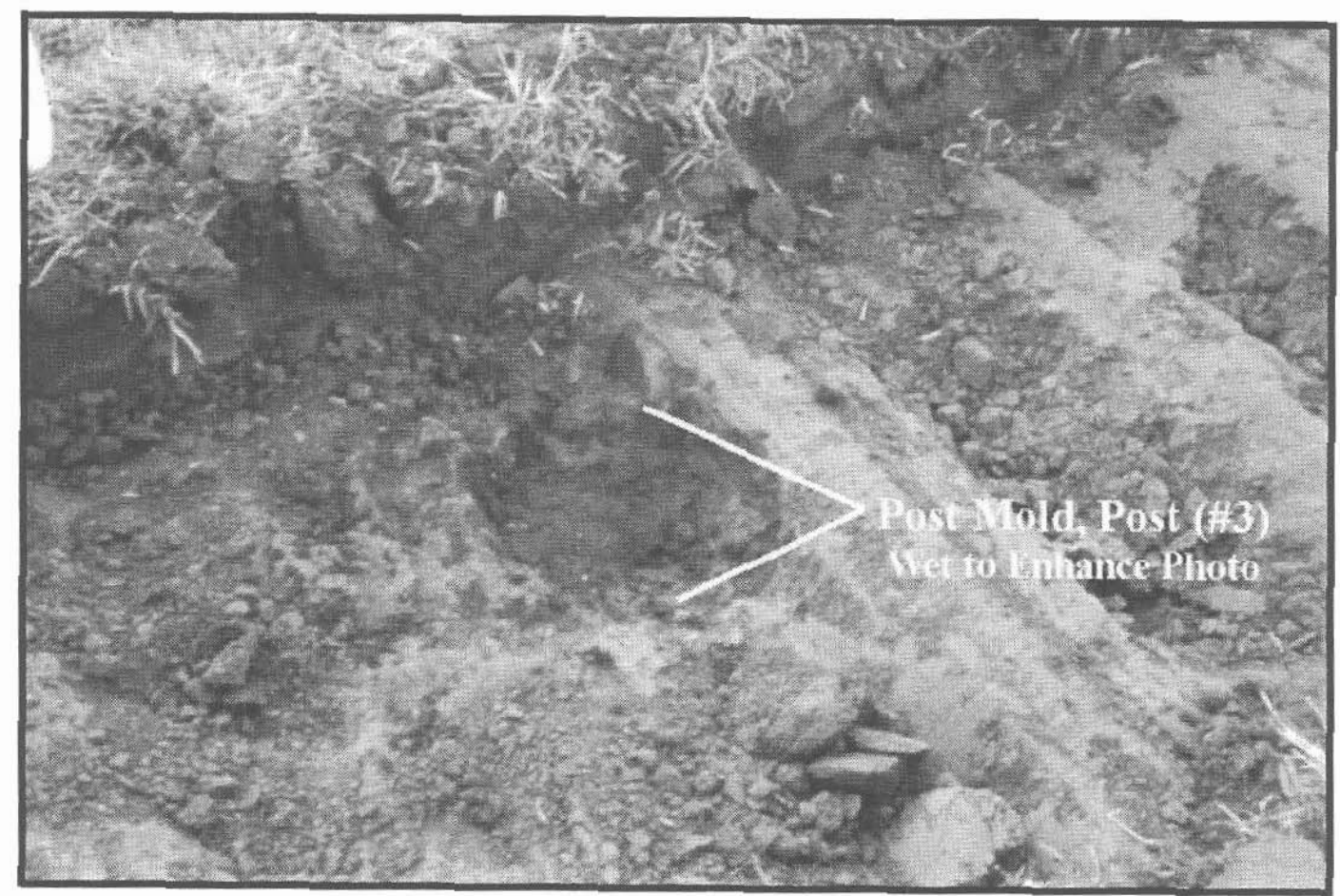

Figure 14: There were no wood fragments left of post \#3 which was located east of and in line with \#s 1 and 2. 




Figure 15: Post mold \#4 was located north of the northeast corner of the brick fireplace base (Feature 2).

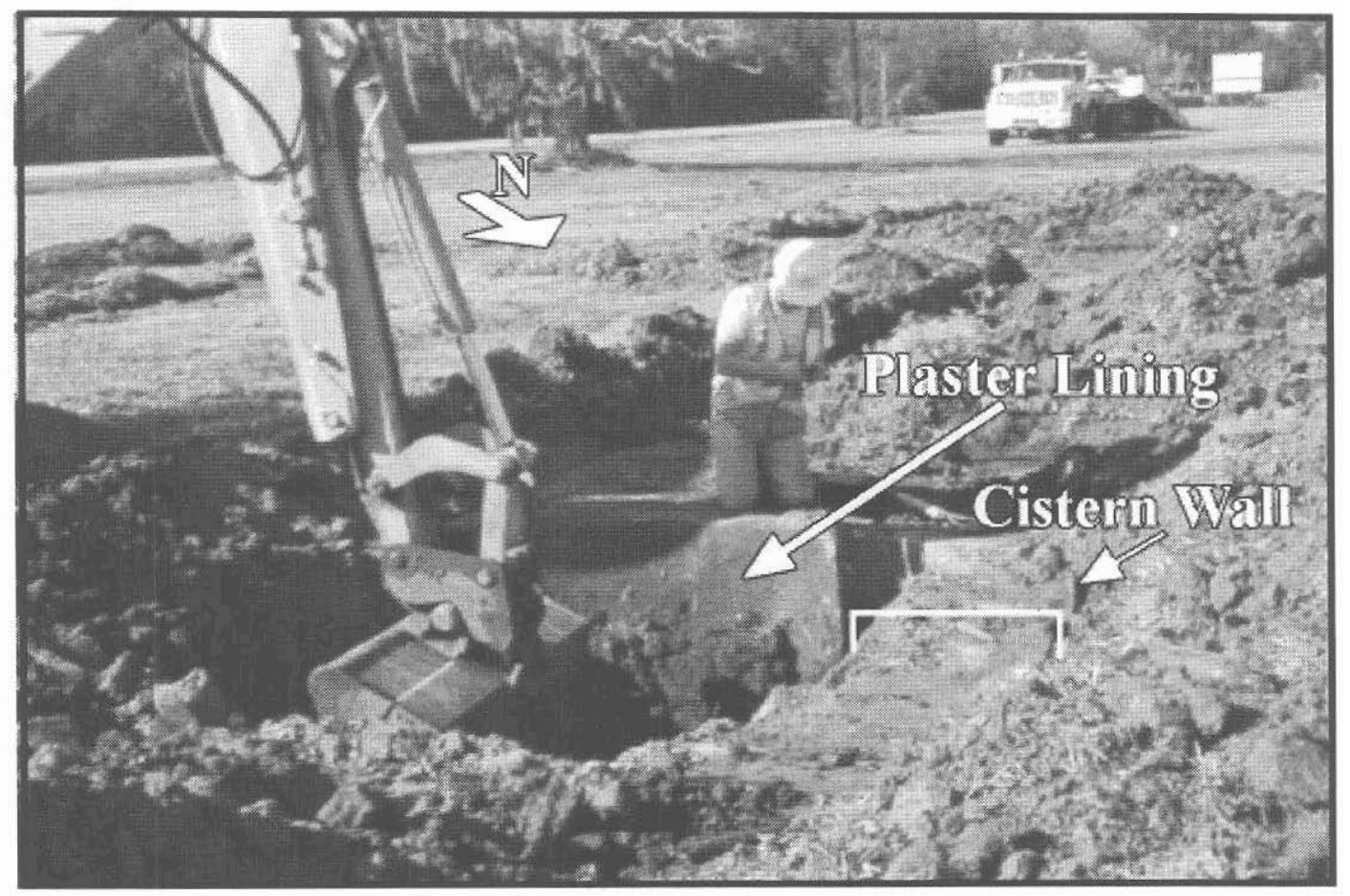

Figure 16: Feature 3, was a brick walled cistern. 
along a fence line. so it was decided to scrape west in a line parallel to the posts of the structure. No additional posts, post molds, or other features or artifacts were identified as a result of this effort (Trench 8, see Figure 9).

The trench was then extended east from the small trash pit and only a few small bits of window glass were present. An attempt to extend the trench further south (Trench 7, see Figure 9) resulted in the disruption of cable television for the entire area. The area south of the newly identified buried cable was a small rise consisting of overburden with small oyster shell fragments.

Visual inspection of the grassy field north of the project area indicated that structures may at one time have been located in line with and extending north of the identified features. There appeared to be a series of small rises at intervals of approximately 60 meters. These were not examined, since they were not within the project area, but may give some indication as to the size of the original site.

An intensive effort was made to locate additional subsurface features to the west of the identified habitation site (see Figure 8), including the privy. Numerous trenches were excavated in this area. Three possible pier supports, exhibited in the form of faint post molds were located near a small tree at the edge of the current right of way. No other evidence of cultural activity was located within the project area.

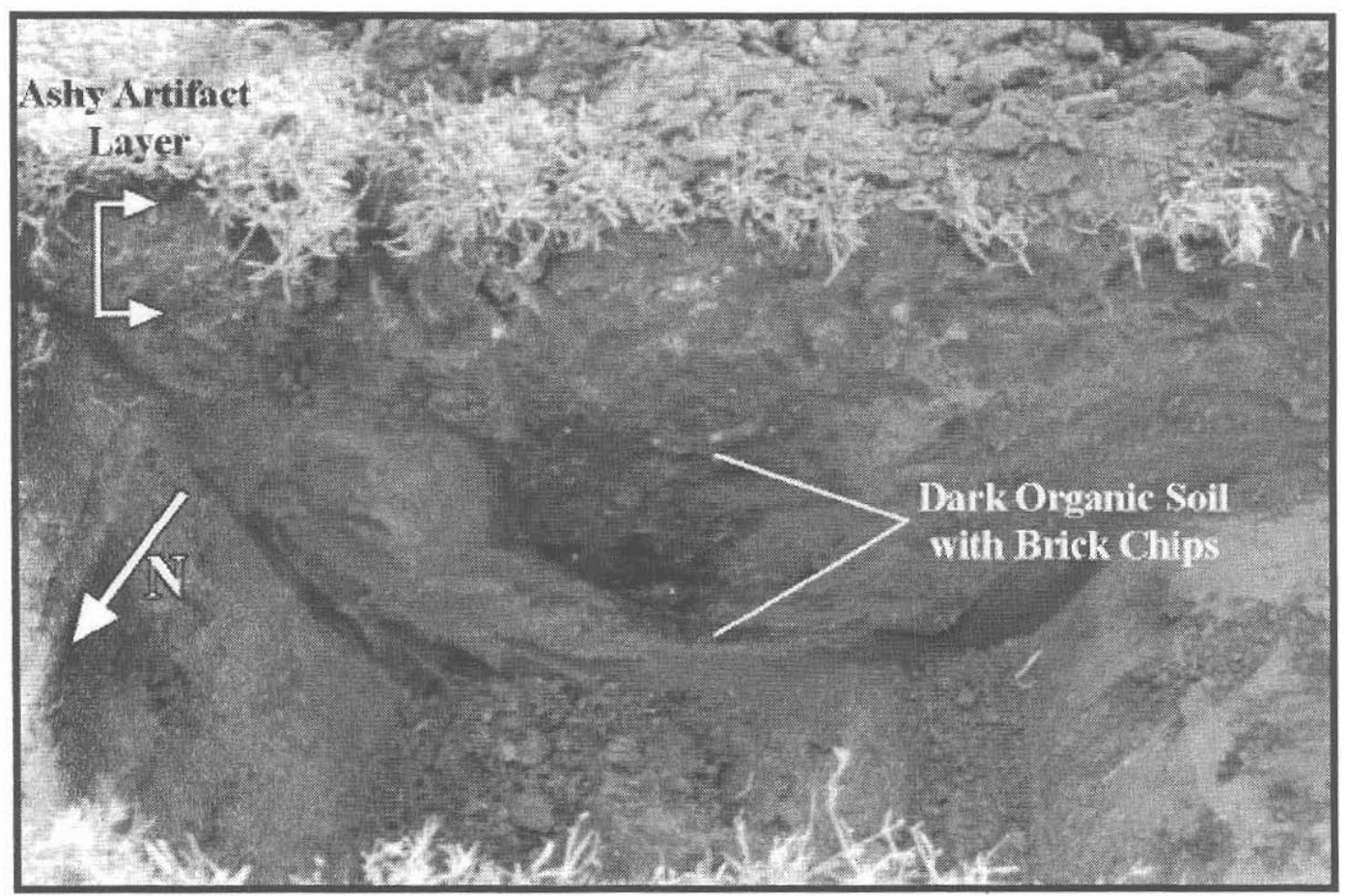

Figure 17: Feature 4 was a burn pit with cast iron stove parts on the surface. The artifacts were recovered from the gray ashy layer just below the grass. The darker soil in the base of the pit did not contain any artifacts. 


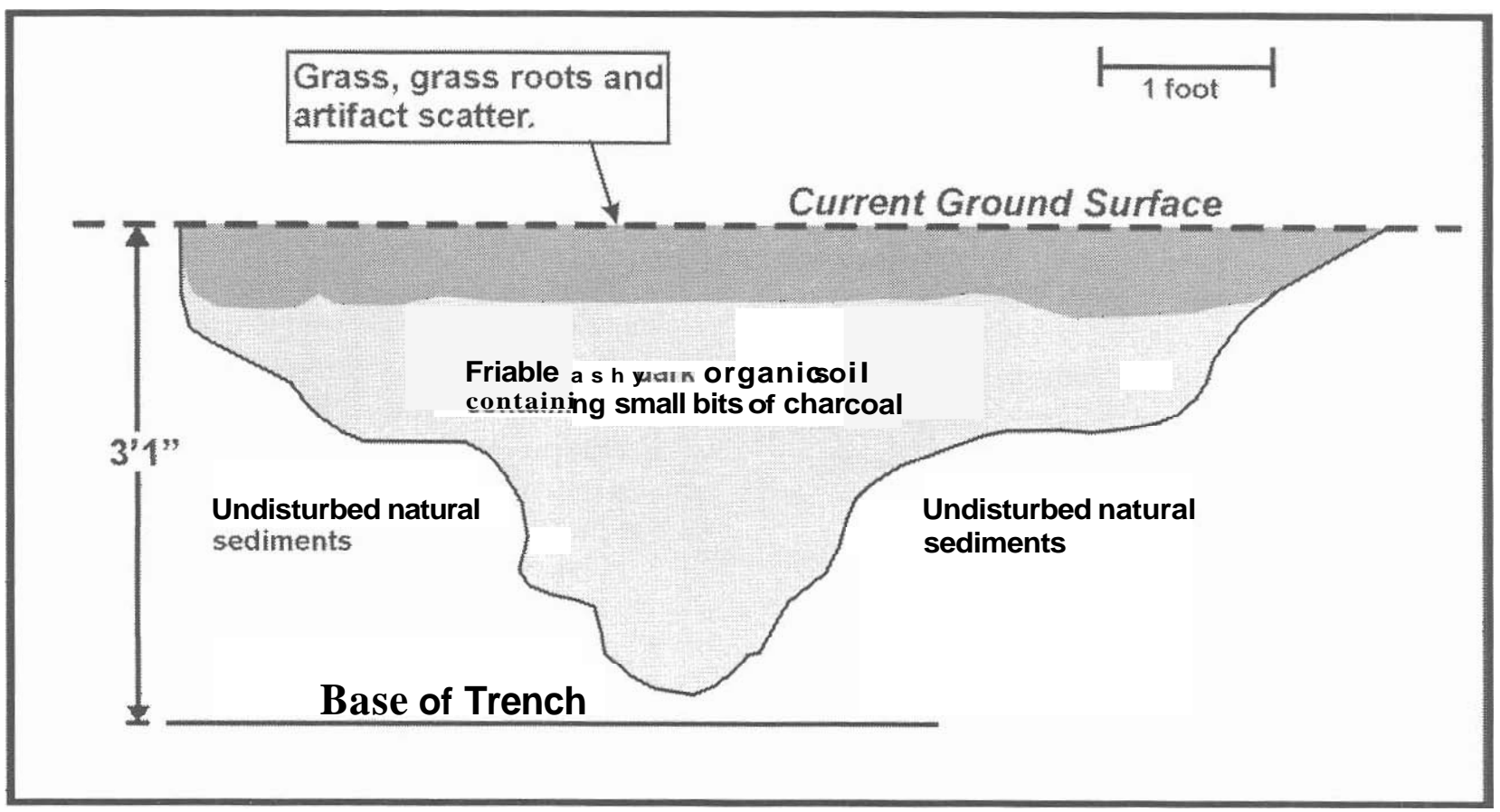

Figure 18: Profile of Feature 4, south wall



Figure 19: Feature 5 was a second brick fireplace base. 


\section{Feature Descriptions}

\section{Feature 1}

A brick scatter was found in the area north of SH 35 and just east of CR 468 (see Figure 5). The brick uncovered in this area was hand made, and dates to the middle of the 19th century. They had been used previously as was evidenced by mortar still clinging to some of the brick. Bricks and fragments were mixed in this single layer scatter. The artifacts associated with this feature are listed in Table 1. The only datable artifacts date after 1890.

None of the artifacts, which were located on the surface of the brick scatter, dated before 1890. Although the whiteware may have been produced and used prior to that time, no datable marks were found, and this type of ceramic is still made.

No functional purpose could be ascertained for the brick scatter. No evidence of a structure, or associated artifacts was found and it was decided the brick scatter was the result of dumping.

Table 1: A rtifacts associated with the brick scatter.

\begin{tabular}{|c|c|}
\hline Description & Date \\
\hline $\begin{array}{l}1 \text { Left Tibia( } 50 \% \text { of proximal diaphasis) } \\
\text { of a deer. The bone is hatchet cut, } \\
\text { evidences some small carnivore chewing } \\
\text { and is heavily rodent gnawed. }\end{array}$ & unknown \\
\hline 1 Brown glass snuff bottle base fragment & Unknown \\
\hline 2 Whiteware fragments & Unknown \\
\hline $\begin{array}{l}1 \text { Clear glass, flask base, fragment } \\
\text { (molded) }\end{array}$ & Unknown \\
\hline $10+$ wire nails & Post 1890 \\
\hline
\end{tabular}

rtifacts in italics were examined in the field but not collected.

\section{Feature 2}

Feature 2 consisted of chimney base which was located by backhoe scraping (Figure 11). The brick surface was just below the grass roots. Two courses of brick remained of the base, which was five feet six inches north/south by three feet east/west. The only artifact recovered near this brick feature was one large cut spike that dates prior to 1890 .

Table 2: Artifact associated with Feature 2.

\begin{tabular}{|c|c|}
\hline \multicolumn{1}{|c|}{ Description } & \multicolumn{1}{c|}{ Date } \\
\hline 1 Spike (cut iron) & $<1890$ \\
\hline
\end{tabular}

\section{Feature 3}

Feature 3 was a plaster-lined brick cistern located by backhoe trenching (Figure 11). The cistern was located east of the brick hearth and post molds which were considered to be evidence of a structure. The cistern was intact to its base. The cistern was 10 feet in diameter and six feet 10 inches deep. The brick used to construct the cistern was hand made soft paste. These bricks date to the middle of the 19th century. The cistern originally was capped with a domed brick top, the remains of which were found within the cistern. Both the brick and the style of cistern construction was the same as that on numerous antebellum sites in the area.

Excavation of the cistern found that all of the cultural material was likely from the 1940's when the cistern was reportedly filled in. Some fiesta ware, stamped November 1947, was recovered from the surface of the sand that filled the cistern. Mr. Weems, the property owner, had indicated that he knocked the top of the cistern in and filled it in 1946 in order to level the field for sod production. No evidence of pre 1900's artifacts was found in association with the cistern.

Table 3: Artifacts associated with Feature 4

\begin{tabular}{|c|c|}
\hline Description & Date \\
\hline I Button - 4 hole glass, pie crust type & unknown \\
\hline 2 Buttons -4 hole shell & unknown \\
\hline $\begin{array}{l}1 \text { Whiteware fragment, Red transfer print } \\
- \text { Platter or serving tray }\end{array}$ & unknown \\
\hline 1 Whiteware rosette, probably a handle & (unknown \\
\hline $\begin{array}{l}\text { I Cast iron fagment with embossed } \\
\text { letters } \boldsymbol{C} \boldsymbol{O} \text { in two places }\end{array}$ & unknown \\
\hline $\begin{array}{l}1 \text { Bayonet fragment (possible Civil War } \\
\text { era) }\end{array}$ & unknown \\
\hline 6 Bone fragments- unidentifiable & unknown \\
\hline $\begin{array}{l}2 \text { Shell fragments - wave worn - } \\
\text { unidentifiable }\end{array}$ & unknown \\
\hline 1 Glass handle fragment - pink, molded & unknown \\
\hline 2 Spikes , square & $<1890$ \\
\hline 9 Whitewarefragments - 1 charred & unknown \\
\hline 1 Cut nail & $<1890$ \\
\hline 2 Oyster shells & unknown \\
\hline 1 Glassfragment - clear,flask & unknown \\
\hline 1 Glass fragment- palegreen & unknown \\
\hline
\end{tabular}


Table 4: Artifacts associated with Feature 5.

\begin{tabular}{|l|l|}
\hline \multicolumn{1}{|c|}{ Description } & \multicolumn{1}{|c|}{ Date } \\
\hline 1 Heavily rusted triangular metal objects & $\begin{array}{l}\text { Unknown, } \\
\text { likely pre- } \\
\text { - possible portions of a bayonet }\end{array}$ \\
\hline
\end{tabular}

Table 5: Artifacts associated with Feature 6.

\begin{tabular}{|l|l|}
\hline \multicolumn{1}{|c|}{ Description } & \multicolumn{1}{|c|}{ Date } \\
\hline $\begin{array}{l}\text { I Milk Glass Disk, scalloped edges with } \\
\text { patent informationon concave side }\end{array}$ & 1886 \\
\hline I Piece of a turtle shell & unknown \\
\hline 1 Mother-of pearl button & unknown \\
\hline 1 Fragment of a porcelain plate & unknown \\
\hline $\begin{array}{l}\text { 1 Whiteware plate fragment decorated } \\
\text { with a brown rim edge }\end{array}$ & unknown \\
\hline $\begin{array}{l}\text { I Small fragment brown glazed } \\
\text { stoneware }\end{array}$ & unknown \\
\hline $\begin{array}{l}\text { 2 Bone Fragments (Portion of the lunate } \\
\text { surface of the acetabulum of a cow } \\
\text { pelvis; distal diaphasis portion of } \\
\text { metatarsus of a cow - hatchet chopped } \\
\text { and with marks indicating meat removal) }\end{array}$ & unknown \\
\hline 7 Unidentifiable metalfragments & unknown \\
\hline $\begin{array}{l}\text { 5 Thin metal fragments (can or metal } \\
\text { tableware) }\end{array}$ & unknown \\
\hline $\begin{array}{l}\text { 1 Wire fragment } \\
\text { 1 Wine bottle glass fragment (opaque } \\
\text { brown) }\end{array}$ & unknown \\
\hline $\begin{array}{l}\text { 1 Mound nails } \\
\text { stretched neck, applied lip) }\end{array}$ & unknown \\
\hline $\begin{array}{l}\text { 2 Clear bottle glass fragments } \\
\text { dable }\end{array}$ & unknown \\
\hline
\end{tabular}

Artifacts in italics were examined in the field but not collected.

\section{Feature 4}

Feature 4 was a pit filled with ash and charcoal (Figure 9). The surface of this pit contained a large number of cast iron stove parts and a small rusted proximal portion of a bayonet. A small amount of crushed shell was present within the ashy matrix. The surface of the pit contained a few artifacts and the soil from this area was screened. The artifacts associated with Feature 4 are listed in Table 3. Only the nails were datable to before 1890 . The area was excavated to the base of the pit and the south wall of the resulting trench was then drawn in profile (see Figure 17, 18).

\section{Feature 5}

Feature 5 consisted of a fireplace base located at the northern limit of the proposed right of way, and aligned at right angles with the fireplace labeled Feature 2 (see Figure 9). The remains of this base were approximately one half brick thick and six feet east/west by four feet north/south (see Figure 19). No artifacts were associated with this feature; however, two metal objects, possibly pieces of a bayonet were found at the southwest corner of the brick feature, on the surface of the soil. These possible bayonet pieces are not datable but were probably made prior to 1900 .

\section{Feature 6}

Feature 6 consisted of small ash concentration located approximately 25 feet north of the current right-of-way line of SH 35 (see Figure 9). The remains of a wooden post were located five feet west of this ash scatter. A few artifacts were mixed with the ash and charcoal. The artifacts associated with Feature 6 are listed in Table 5. The datable artifacts were deposited after 1886 .

\section{Posts and Post Molds}

A total of 10 posts or post molds were located during the testing of 41B 0185 (see Figure 9). Post 1 and post molds 2 and 3 are in a line east/west, 6 feet south of the fireplace, Feature 2. This line of posts probably supported the beam for the south wall of the structure.

\section{The SCrape west Of Feature 2}

The largest number of artifacts were recovered from a scrape (Feature 2) west of the fireplace base. Other than Feature 2, no features could be found in association with this broad thin artifact scatter (see Figure 9). The artifacts associated with this area are listed in Table 6. Although the dates for these artifacts vary, there were many that dated to 1890 and after. 
Table 6: Artifacts associated with the scraped areas West of Feature 2.

\begin{tabular}{|c|c|}
\hline Description & Date \\
\hline 1 Ironstone earthenware (Royal Patent Ironstone. Burgess \& Goddard) & $>1883$ \\
\hline 3 Yellowware fragments of a crock lid. With blue and white annular type decoration & Unknown \\
\hline I Yellowware with Rockingham decoration. Unusual rim fragment & Unknown \\
\hline $\begin{array}{l}\text { I Whiteware fragment (Blue floral transfer Print - Too fragmentary to identify pattern, but printed on both sides = } \\
\text { large serving piece or wash bowl) }\end{array}$ & Unknown \\
\hline $\begin{array}{l}\text { Fragments( } 2 \text { base, I neck) of whiskey flask( "shoo-fly" or coffin flask) with an A inside a circle on the bottom with } \\
\text { a ring lip neck finish above a narrow beveled ring }\end{array}$ & $1865-1890$ \\
\hline 2 Whiteware cup handles & Unknown \\
\hline Medicine embossed bottle body fragments ( 1 clear glass, 3 pale blue) unidentifiable & Unknown \\
\hline $\begin{array}{l}2 \text { Medicine bottle neck fragments ( } 1 \text { clear glass, } 1 \text { pale blue) molded bottles w/stretched necks. One has rim missing } \\
- \text { one is an Oil or Ring finish }\end{array}$ & Unknown \\
\hline $\begin{array}{l}\text { Brown glass bottle fragments ( } 2 \text { base I neck). Molded bottles base has embossed letters A B C M. Neck is } \\
\text { stretched with Bead finish. }\end{array}$ & Unknown \\
\hline 1 Molded glass bowl fragment. Has a small floral design with leaves & Unknown \\
\hline Drinking glass base, pale green & Unknown \\
\hline 2 G lassfragments ( 1 rim piece, clear frosted \& I body fragment dark green frosted) & Unknown \\
\hline 7 Buttons ( 3 china, 2 glass pie crust type, 1 black glass, 1 small 4 hole shell) & Unknown \\
\hline I Decoratively molded cast iron fragment, piece of cook stove & Unknown \\
\hline I Brass shell casing, center tire no marks & Unknown \\
\hline 79 Bone Fragments & Some $>1900$ \\
\hline 130 yster shell halves of the size and a ppearance that they were used as a food source & Unknown \\
\hline 11 B rown glass snuff bottle fragments & Unknown \\
\hline $100+$ Window glass fragments & Unknown \\
\hline 23 Round $\mathrm{n}$ a ils various sizes heavily rusted & $>1890$ \\
\hline 9 Unidentifiable metal globs -2 appeared key shaped & Unknown \\
\hline 14 Cut nails & $<1890$ \\
\hline 50+ Whiteware fragments unmarked- not datable & Unknown \\
\hline 1 C astiron - flat- possible stove part & Unknown \\
\hline 22 Flask bottle fragments(" shoo-fly"or coffin flask with a ring lip neck finish above a narrow beveled & $5-1890$ \\
\hline
\end{tabular}

Artifacts in italics were examined in thefield but not collected. 


\section{ARCHIVAL RESEARCH}

\section{Aerial Photograph}

An aerial photo (Figure 20), taken November 4, 1930, was examined for evidence of structural remains, roads, or other features that may have been present at a time prior to Mr. Weems purchase of the property in 1947. Portions of this photo were examined in detail, enlarged and overlain with the locations of trenches excavated and features located during the testing. It appears that a possible privy was located west of the tree at the north edge of the SH 35 ditch. A dark stain can be seen in the side of the then newly created ditch on the photo. This area was scraped with a shovel in an attempt to locate privy deposits, but no deposits were found. The privy contents may have been removed over the years as part of the SH 35 ditch maintenance program.

Also visible on the aerial photo is the location of the cistern, and some dark areas which appear to be yard areas with lighter areas adjacent that appear to represent the locations of the structures (see Figure 20). A road or trail appears to enter the project area from near the location of the intersection of SH 35 and CR 468 and pass just south of the largest dark area. This road then dips south and converges with SH 35 near the driveway of a private residence west of the current project area. This road was not in use at the time the photo was taken, since roads that were in use clearly show up as white scars on the photo. The path to what may be a privy is also visible through the dark backyard area, beginning just north of the fireplace base (Feature 2) and arching down to the possible privy area. Other paths appear to be visible on the photo but are very ephemeral.

Upon detailed examination of the photo it appears that the brick scatter is visible in the area just east of CR 468 (see Figure 20). The woods were not as dense when the photo was taken and the large oak tree under which the scatter now rests was smaller.

\section{Property Title}

It was discovered during the background research that two fairly substantial and permanent Civil War Era camps were located in the West Columbia area. One was Camp Bernard Bee, named after the brother of Gen. Hamilton P. Bee, the first commander of the Western SubDistrict of Texas. The other was Camp Slaughter, named after Gen. James E. Slaughter the second commander of the Western Sub-District of Texas. Camp Slaughter is also described as having been locatedon land belonging to $\mathrm{Mr}$. Brown at the time of the Civil War.

The Brazoria County Deed Records (BCDR), located at the Brazoria County Court House in Angleton, Texas were accessed and an attempt was made to determine ownership of the project area during the Civil War. The state of Texas purchased the land from Marcus A.



Figure20: A erial Photograph of Project Area. When this picture was taken on November 4. 1930; SH 35 was a gravel road and neither CR 438 nor the road at the western edge of the sod field exited. 
Weems in 1999 (BCDR 413/60). Marcus Weems purchased the land from M.P. Finkelstein on March 7, 1947 (BCDR 4131600) and Mr. Finkelstein had purchased it from J. H. Underwood on May 23, 1917 (BCDR 1381287).

In Vol. 138 P. 287 (BCDR) Underwood sold the 40113 acres to M. B. Finklestein it was known as the Shapard place. Underwood reserved the crop growing on the land until January of 1918 and also retained possession of the house and pasture until the crops were gathered. This deed references Vol 134 P. 367 (BCDR) which gives specific metes and bounds of the property for the purposes of an oil lease but does not reference a deed of sale.

Underwood purchased the land from J. H. Snow on Sept 25, 1908 (BCDR 811391). Prior to 1908 the chain of title is less certain. It appears that J. H. Snow sold this same land to G.H. Sweeney in April of 1901 and according to the deed in Vol. 81 p. 391 Underwood purchased only one square acre of land. A deed exists that shows that Underwood leased the land from J. L. Dullans in July of 1898 and then signed an oil lease in May of 1917 which references the metes and bounds of the land leased, but no reference is made to the deed of purchase. The deed for the sale of the land from Underwood to Finkelstein references this oil lease deed instead of the actual deed of purchase so the chain for the reverse transfer of property is lost at this point.

Although there was not time to trace the specific piece of property there is no evidence that any lands from the Josiah Bell patent were ever purchased by a Mr. Brown. The name Shapard also appeared in these records many times but it was not clear if one of them had owned the project area which in 1918 was sold by Underwood to Finklestein. It is possible that a more complete chain of title could be established, however, since the land did not belong to $\mathrm{Mr}$. Brown during the Civil War it is unlikely this was the location of Camp Slaughter.

The name Shapard does appear in Texas at an early date when a license was issued in Washington County for the marriage of John W. Brooks to S. Jane Shappard on November 26, 1847 (Ray 1970; 204).

\section{ARTIFACTANALYSISRESULTS}

All of the recovered bone was collected and returned to the lab for analysis. Of the other artifact types found, only those specimens or fragments with diagnostic potential were returned to the archeology laboratory for analysis.

\section{Nails}

Nails provide one excellent source for dating historic period sites. The Gulf Coast area of Texas was settled during a time when the production of cut nails was being improved. By the 1820's a nail making machine had been developed that produced uniform nails in a quick and efficient way. Both nails exhibit square bodies, but the nails produced by the earlier method, between 1790 and 1830, have small burrs on the diagonally opposite edges. Cut nails produced by the new method can be identified by the location of the burrs on the same side. These nails were used from 1820 to 1900 . By about 1886, 10percent of the nails produced in the United States were made of soft steel wire. By 1892 more steel-wire nails were being produced than iron-cut nails, therefore, a date of 1890 is chosen for the advent of the round nail in Brazoria County (Visser 1996). Although some cut nails were recovered from 41B0185, the majority of the nails present at the site were round.

\section{Ceramics}

Ceramics can frequently provide dates of manufacture. Depending on the makers marks recovered from a site, dates can be specific, or within a range. Hand painted and transfer print wares can frequently be dated by identification of the design. As styles and techniques changed, design applications and styles changed. These changes have been documented and when identifiable they can be used to place a piece of ceramic within a specific period. Large amounts of broken ceramic from archeological sites are often not datable because they do not exhibit a makers or exporters mark and they have no identifiable pattern. With that in mind, the few ceramic pieces with the potential to provide temporal information were examined. 
A piece of whiteware was discovered in the artifact scatter to the west of Feature 2 which had a partial mark (Figure 21:A). The word "ROYAL" can be read below an image, most of which is missing. Below that is "PATENT IRONSTONE and below that is "BURGESS \& GODDARD".

In July of 1813 a patent was taken out by Charles James Mason for "a process for the improvement of the manufacture of English
Porcelain" which was called "Ironstone" (Godden 1965). The words in block print all capitol letters "MASON'S PATENT IRONSTONE CHINA" or "PATENT IRONSTONE CHINA," appeared in use between 1813 and 1825 in different forms and impressed in one line, in two or more lines or in circular form (Godden 1964). From 1820 onward the mark included a crown and banner. Between 1813 and 1848 large amounts of "Patent Ironstone" were produced.

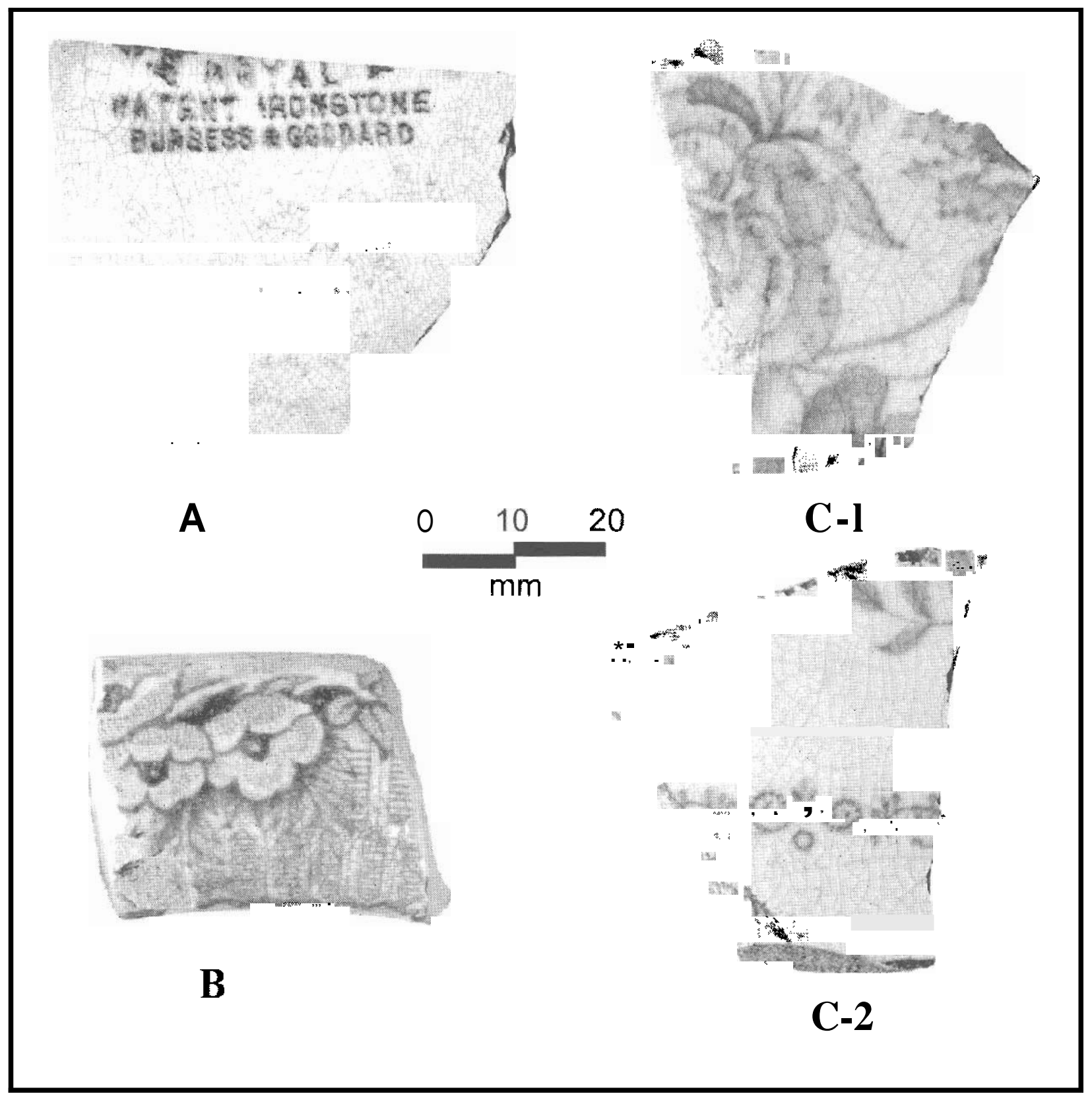

Figure 21: A - Ironstone China, discovered in the artifact scatter west of Feature 2. B - Red transfer Print ceramic, lip edge of shallow dish. C-1 - Blue transfer print ceramic, the fragment is too small to identify the design and date the fragment. $\boldsymbol{C}$-2 - Reverse side of C-1 ceramic fragment. 
This heavy durable body was extensively employed for dinner and dessert pieces and because it was robust, was well suited to the expanding world markets of the nineteenth century (Godden 1975).

In 1848 Charles J. Mason became bankrupt, and most of the molds and patterns were purchased by Francis Morley who was in partnership with George Ashworth from 1858 to 1862 (Godden 1965). From 1862 George L. Ashworth \& Bros Ltd., traded at Hanley and then sold out to J. H. Goddard in 1883 , whose descendants continue to use the designs and shapes of C. J. Mason to this day (MacDonald-Taylor 1962).
However, Turner, Goddard \& Co., Royal Albert Pottery, from 1867 to 1874 , produced a mark dated July 1867, which reads "ROYAL. PATENT. IRONSTONE. TURNER. GODDARD \& CO" (Godden 1964).

The name Burgess first appeared in 1862, in Staffordshire, England as Burgess \& Leigh (Ltd.). By 1864, Henry Burgess was producing pottery with his own mark. Although the mark Burgess \& Goddard was not found for this research, it is clear that both Burgess and Goddard were in business in Staffordshire during the latter portion of the 19lhcentury. The right to use the term "patent ironstone" became the

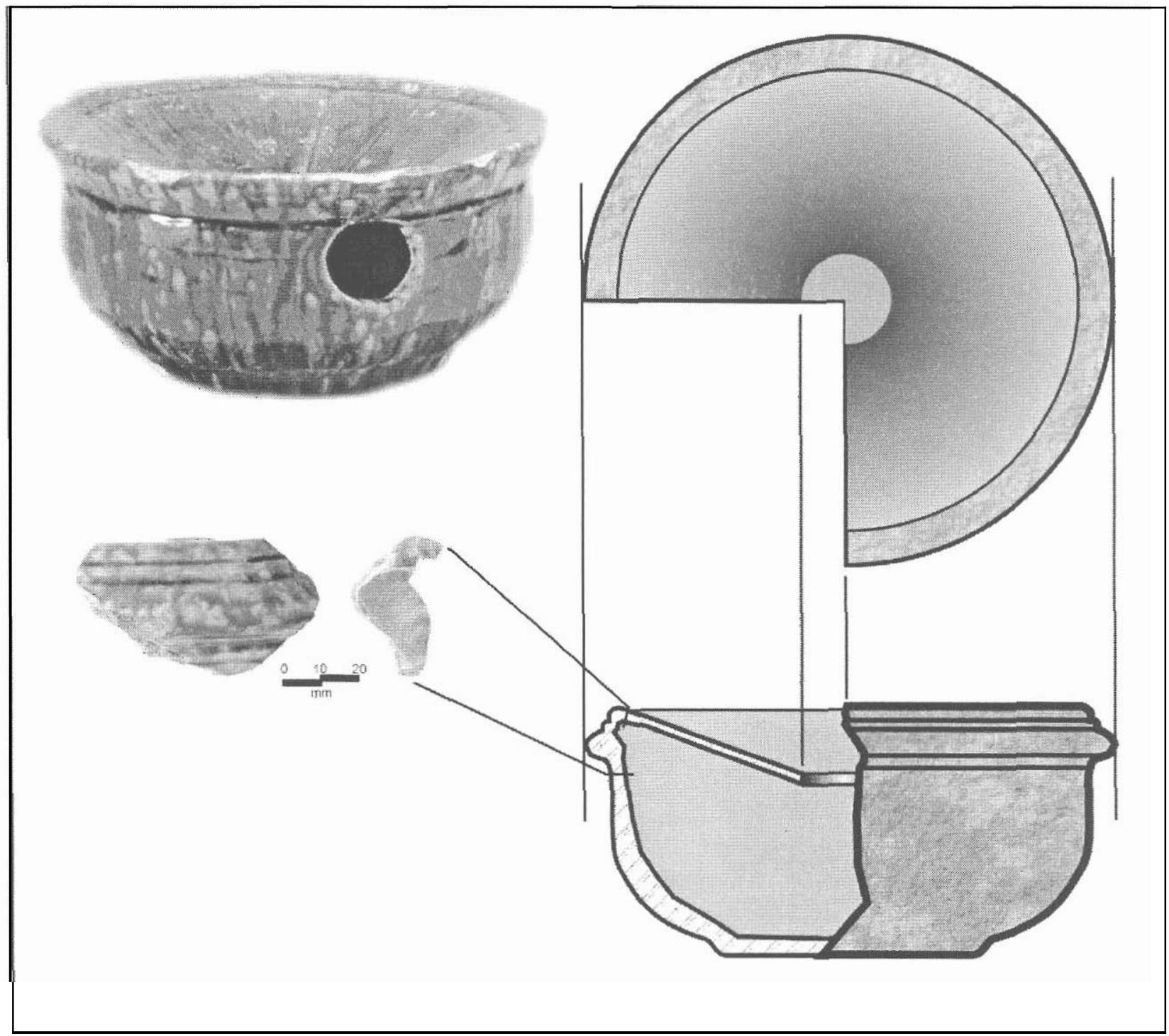

Figure 22: The whole vessel, upper left, was discovered at Johnson's Island, a Civil War prisoner-of-war camp in Ohio, it is a yellowware vessel with a brown Rockinghamdecoration. The small rim sherd, center left, comes from 41B 0 185, the artifact scatter west of Feature 2. It is apiece of a yellowware vessel with a brown Rockingham decoration. 
property of Goddard in 1883. In all probability this piece was produced in Staffordshire, some time after 1883.

A small rim fragment of a yellowware vessel with a brown Rockingham decoration (Figure 22) was found among the artifact scatter to the west of Feature 2. Although there is no mark on this piece, the shape of the rim suggests it was a spittoon, similar to the one discovered at Johnson's Island (Bush 2000). Johnson's Island is in Sandusky Bay, just south of Marblehead Peninsula, Lake Erie, Ohio, and was the location of a military prison for confederate officers during the American Civil War. Unfortunately this does not mean that the piece recovered from 41B O185 dates to that period, but leaves open the possibility that it might.

\section{Glass/B ottles}

Two base fragments and a neck fragment of a clear glass possible whiskey flask were recovered from the artifact scatter west of Feature 2. The flask is molded with a stretched neck and applied lip. The shape is Shoo-fly. On the base of the flask there is a capital A in a circle and the neck treatmentis a ring lip finish above a narrow, beveled ring.

A white milk glass disk with scalloped edges and a broken stem (Figure 23: A-C) was recovered from Feature 6, the small trash pit on the south edge of the project area. The disk has a number of dates molded into the surface, the latest complete date is July 20, 1886. Other dates are "? 12, 76; Nov. 30, 86; Nov. 23, ?" and the letters "PAT D". The earliest date this object could have been deposited on the site is 1886 , however, it's function was in doubt. Research into patent information was conducted and it was discovered that the object is a jar lid liner intended to hold the fruit or pickled produce below the level of the liquid thereby preventing spoilage of those pieces at the surface. The original patent was issued to Elizabeth S. Hunt of Cleveland Ohio in September of 1876 (Figure 23, D-1). In March of 1886 the patent for the object recovered from 4 IB O185 was issued to William Somerville of St. Louis Mo. (Figure 23: D-2).

\section{Faunal Remains}

A total of 79 bone fragments were recovered $f r o$ the artifact scatter area to the west of Feature 2. These included bones of pig, cow and turtle. No small mammal bones were recovered. Some of the bones had been butchered into standard supermarket cuts using powered saws. Some of the bones exhibited butchering with a hatchet and with a hand saw. There was evidence of large carnivore chewing, probably a dog, however, this is not extensive and it does not appear that the bones were left accessible to scavenging for any great length of time. Bones which exhibit butchering with power equipment came into widespread use around 1900.

\section{FEATURE INTERPRETATIONS}

The features located by subsurface field investigation included two fireplace bases, a cistern, a burn pit near what may have been shed supports and a concentration of ash near what appeared to have been a fence post. These features along with the scatter of artifacts all seem consistent with the presence of a turn-ofthe-century homestead. The brick were made of soft paste and may have been salvaged to build the cistern and chimneys for the house which was of post-and-beam construction. This site could also have been the result of reuse of what had once been structures constructed during the Civil War for military purposes, which would explain the military artifacts reportedly recovered from the area by local informants. Military artifacts are frequently found on homesteads dating to the last half of the 19thentury, since soldiers brought such things home from the war.

\section{CONCLUSIONSAND RECOMMENDATIONS}

The area recorded as archeological site 4 1B 0185may at one time have been the location of a Civil War Era military camp. The brick used for the chimneys and cistern appear to date to that time period. However, the consistent use of the property for the cultivation of sod has removed any artifactual evidence of the area's 


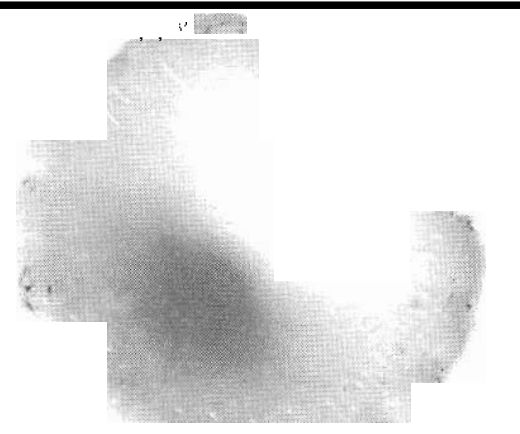

A

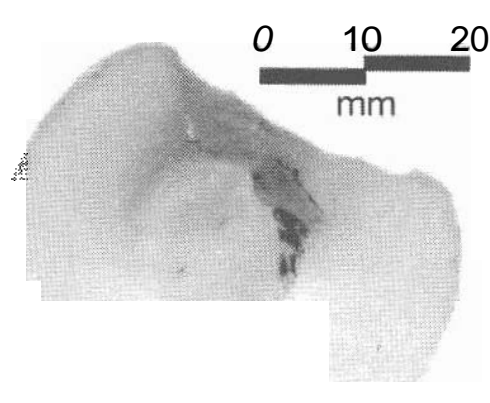

B

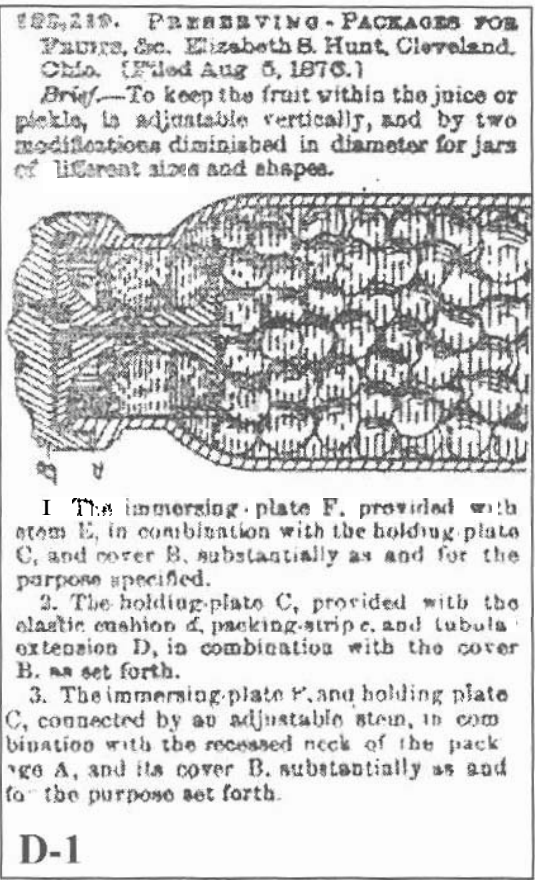

C

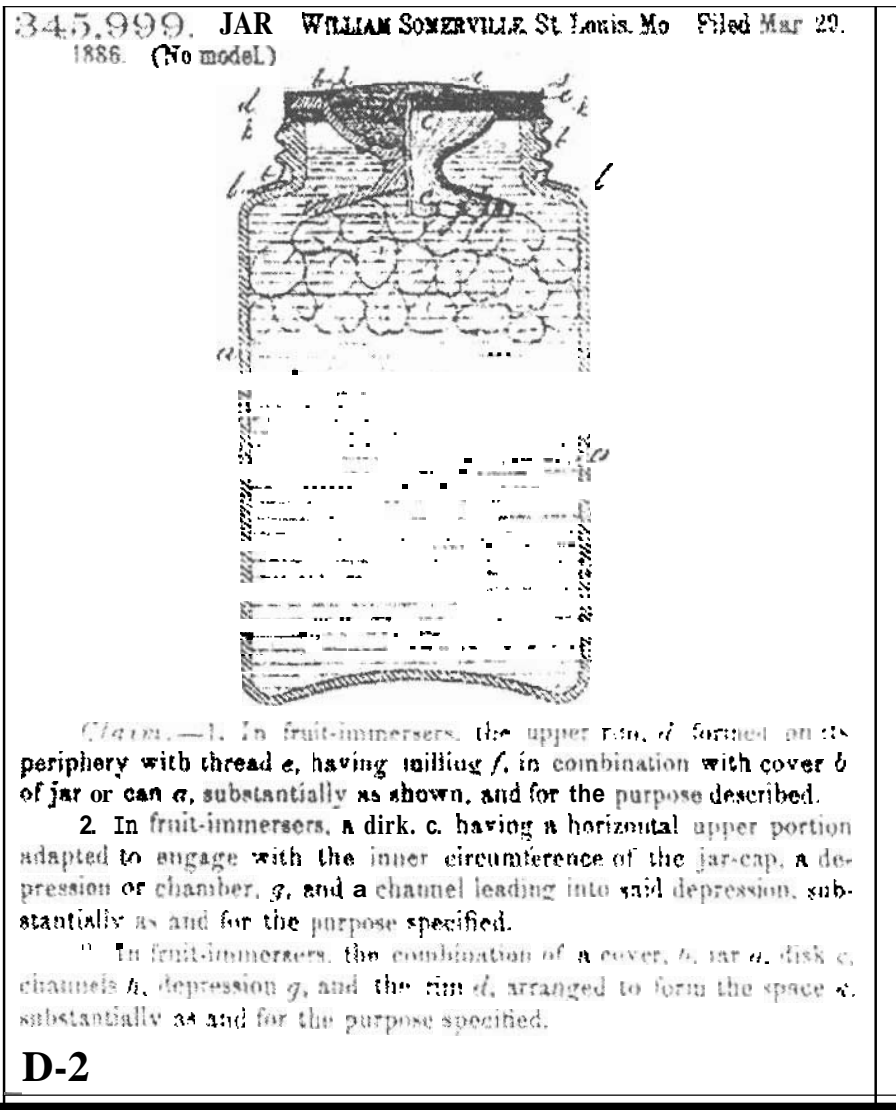

Figure 23:A whitemilk glass disk with scalloped edges was recovered from Feature 4,4180185. A- the underside of this disk contained patent information that resulted in the identification of it's function. B - The stem section of the artifact is broken. $\mathrm{C}$ - the scalloped edges of the disk led to the belief that it might be decorative rather than utilitarian. D-1 - Copy of the original Patent September 12, 1876. D-2-Copy of the July 20, 1886 patent, both published in theUS Patens Official Gazette U.S. Patent Office microfilmedby RP. Woodbridge, Conn.Research Publications. Inc., 06252. 
use as a Civil War era installation if indeed it ever existed. The harvesting of sod is done with machinery which slices the soil approximately $1 / 2$ inch below the ground surface and removes this soil along with the grass sod and roots to be sold for installation at another location. Mr. Weems stated that as much as I0 inches of soil had been removed from the project area during the years he operated his sod farm on the site. The fact that Feature 5, the northern brick fireplace base, consisted of a layer of brick only one half brick thick testifies to the almost complete destruction of the site, it's artifacts, and features as a result of previous agricultural activity and clearing.

If the site was used as a Civil War military camp, there is no evidence of that era within the expanded TxDOT right-of-way. The only evidence that remains is of what appears to be a turn of the century homestead and even that is minimal. The brick scatter east of County Road 468 , consists of only dumped bricks. Their original location and use cannot be ascertained.
Only an artifact scatter, some post molds, a cistern devoid of historic cultural material, and a couple of ashy deposits containing almost no artifacts remain; and these date to a period between 1883 and 1947.

Previous disturbance by agricultural activities has removed or destroyed any deposits that may have been at this location. The portion of previously recorded archeological site 41BO185 within the current and proposed TxDOT right-of-way, a strip 100to 125feet wide and nearly 1500 feet long (approximately 4 acres) contains no archeological deposits with the integrity to be eligible for inclusion in the National Register of Historic Places or to warrant designation as a State Archeological Landmark.

Additional work north of the currently explored location may be able to locate features which could provide information about site use prior to 1900 . However, it is doubtful this work would be fruitful given the removal of so much soil from a site of such recent origin. 


\section{REFERENCES CITED}

Beers, Henry Putney

1986 The Confederacy, A Guide to the Archives of the Government of the Confederate States of America. National Archives and records Administration, Washington, DC.

Bush, David

2000 Johnson's Island Civil War Military Prison. University of Pittsburgh. Retrieved February 1I, 2000 from the World Wide Web: http://www. heidelberg.edu/-dbush/ jirev2.html

Crenwelge, Gerald W., et al.

1981 Soil Survey of Brazoria County, Texas. United States Department of Agriculture,Soil ConservationService.

Godden, Geoffrey A.

1964 Encyclopaedia of British Pottery and Porcelain Marks. Bonanza Books, New York.

1965 An Illustrated Encyclopedia of B ritish Pottery and Porcelain. Bonanza Books, New York.

1975 British Pottery an Illustrated Guide. Clarkson N. Potter,Inc., New York.

Kovel, Ralph and Terry

1975 The Kovels' Complete Antiques Price List. Crown Publishers, Inc., New York.

MacDonald-Taylor, Margaret, editor

1962 A Dictionary of Marks, Ceramic Metalwork Furniture, The Identification

Handbook for Antique Collectors. Hawthorn Books, Inc., New York.

Ray, Worth S.

1949 Austin Colony Pioneers. The Pemberton Press, Jenkins Publishing Company, Austin and New York.

Visser, Thomas D.

2000 Nails: Clues to a Building's History. Found online at http://moose.uvm. edu/-histpresl h p 203 / n U 1 February 16,2000.

Vlach, John Michael

1993 Back of the Big House, The Architecture of PlantationSlavery. The University of North Carolina Press, Chapel Hill and London.

Winsor,Bill

1978 Texas in the Confederacy, Military Installations, Economy and People. Hill Jr. College Press, Hillsboro, Texas. 